\title{
5. Does the German social model support the convergence of living conditions in the EU?
}

\section{Gerhard Bosch}

\section{INTRODUCTION}

The European Community was not conceived merely as an economic union, in which, once barriers to trade had been reduced through the play of market forces and the mobility of the factors of production, living standards in the poorer countries would converge with those of the wealthier countries. Economists categorise such catch-up processes as 'beta-convergence'. The European Union (EU) also talks of a European social model, by which is meant not only that social standards should converge towards a minimum level, but also that they should be further developed in order to establish fair working and living conditions and equality of opportunities. The aim is to reduce social inequality within member states and the EU as a whole, a process termed 'sigma-convergence'. Both convergence criteria belong together, because increasing social inequality hampers growth (Ostry and Berg 2014), and thus also beta-convergence, if too little is invested in the life opportunities and therefore also the human capital of disadvantaged groups, thereby causing consumer demand to stagnate.

Germany is one of the wealthiest EU member states; it might be surmised, therefore, that the question there would be less about catch-up processes than about maintaining prosperity. However, following German reunification and the integration of the poorer part of the country after the fall of the Iron Curtain, the organisation of such catch-up processes has determined German economic policy to date. The various solidarity pacts intended to provide aid for eastern Germany are the functional equivalent of the EU's cohesion fund. Also, social inequality within Germany has increased considerably in the past two decades. This is linked not to reunification but to the deliberate policy goal of weakening the once inclusive wage system and to a redistribution from the bottom to the top, primarily through tax policy (Bach et al. 2016). Growing inequality in the EU member state with the largest population has acted as a brake on sigma-convergence in the EU as a whole. There is also the question of whether Germany, with its growing current account surpluses within the straitjacket of European austerity policy, is hindering other countries' catch-up processes (beta-convergence).

Consequently, the convergence debate cannot be conducted on a country by country basis, because in a common economic area - and even more so in a monetary union - a policy adopted by one country (particularly the largest country) can have both positive and negative effects on the convergence processes in other countries. After the experiences of recent years, we surely have to bid farewell to the naive hope of the EU's early years that all member states would grow and prosper together. 
Convergence will not occur spontaneously; there must be a political will to achieve it and it has to be actively managed. The EU's cohesion funds are intended expressly to support the weaker countries and regions in initiating catch-up processes. European Union social policy directives are intended to ensure that all member states adhere to common minimum standards. However, unlike the transnational regulation of the internal market, with binding rules for all member states, social policy is governed by the subsidiarity principle, according to which individual member states themselves are responsible for implementing common objectives. Consequently, the 'European Pillar of Rights' proclaimed and signed in Gothenburg in 2017 is not binding and has therefore been adopted only in the weak form of '20 Principles' (EC 2017b). The declaratory nature of the principles reflects not only the EU's limited competence but also the diversity of opinion among the actors in the EU, not all of whom by any means wish to reduce inequality. On the contrary, many of them see social standards only as obstacles to growth (Palley 2013).

The purpose of this chapter is to examine the role of industrial relations in Germany in advancing both forms of convergence. It begins with a brief survey of the basic characteristics of the German industrial relations system, which will serve as a basis for formulating realistic expectations of its contribution (section 2). This is followed by an analysis of German wage policy and its influence on Germany's growing current account surpluses, which are destabilising Europe. In particular, we address the question of whether wage restraint facilitated by the continuous erosion of collective bargaining would be the right lever with which to bring about increased growth and living standards in a country and to achieve upward economic convergence (section 3 ). The next section investigates the growing income inequality in Germany, the most important cause of which is the deregulation of product and labour markets (section 4). This is followed by an analysis of the evolution of employment in general and of the various forms of precarious employment in particular, focusing on the regulation of precarious employment forms in Germany, whose expansion is also a factor in the growing inequality. In addition to national regulations, EU directives also play an important role in this area (section 5). Two case studies follow. The unequal distribution of working time is one significant factor in the increasing inequality. Since decisions on the duration of working time in Germany are made primarily in collective agreements and at company or establishment level, this is a key issue in industrial relations and the first case study (section 6). Section 7 comprises the second case study. I investigate the impact of Germany's new minimum wage on pay, employment and collective bargaining, and the strong influence of the social partners on the minimum wage. Section 8 concludes.

\section{MAIN CHARACTERISTICS OF THE GERMAN INDUSTRIAL RELATIONS SYSTEM}

The German industrial relations system is characterised as autonomous: the social partners negotiate wages and many other working and employment conditions without state intervention, with the outcomes being incorporated into industry-wide collective or company agreements. The social partners' influence on the processes of distribution depends on their respective power resources (Korpi 2006) and their ability to deploy those resources strategically and effectively (Lèvesque and Murray 2010). The 
power resources are a product of their organisational and institutionalised power. The term 'organisational power' denotes the internal resources that can be called on in distributional conflicts; they include size of membership, financial reserves and narrative resources to convince broad sections of the populace of their demands. Institutionalised power is produced by deploying power resources via important institutions in the social dialogue and employment systems.

The state seldom intervenes in the negotiation processes but has strengthened the institutionalised power of the weaker side, namely, the employees and their representatives. The distinction Sengenberger (1994) makes between protective and participatory standards is useful in helping us to understand the various ways in which the state influences industrial relations. The state can establish pay norms by putting in place protective standards such as minimum wages and the power to make collective agreements generally binding. Alternatively, participatory standards give employees and their representatives and organisations consultation or codetermination rights, and endow them with the resources (time and money) to exercise those rights and protect them from disadvantage and discrimination. In this way, the state can enable third parties to determine working and employment conditions in its place.

The particularities of German industrial relations can be identified most readily by means of a brief international comparison. Table 5.1 shows that in Germany the state scarcely intervenes in wage negotiations by means of protective standards. The national minimum wage was not introduced until 2015, when the social partners were no longer in a position to constrain the expanding low-wage sector without assistance. However, participatory standards are very high. Works councils have extensive information and codetermination rights, and are well protected against dismissals. Furthermore, they are guaranteed resources in the form of both time and money (release from duties, staff and paid further training). In addition, there is parity codetermination (equal numbers of employer and employee representatives) on the supervisory boards of larger limited liability companies, with strong information rights. Works councillors are the backbone of the German trade unions. In 2010, around 174000 works councillors were elected by

Table 5.1 Protective and participatory standards in five national wage-bargaining systems between the social partners, Germany and selected EU countries

\begin{tabular}{|c|c|c|c|c|c|}
\hline & Germany & Sweden & UK & France & Belgium \\
\hline Protective standards & $\mathrm{X}$ & - & $\mathrm{X}$ & XXX & XXX \\
\hline Participatory standards & $\mathrm{XX}$ & XXX & - & $\mathrm{X}$ & $\mathrm{XX}$ \\
\hline Trade union density (2013) & $18 \%$ & - & $26 \%$ & $7 \%$ & $55 \%$ \\
\hline $\begin{array}{l}\text { Coverage by collective } \\
\text { agreement in } \% \text { (2013) }\end{array}$ & $58 \%$ & $89 \%$ & $30 \%$ & $98 \%(2012)$ & $96 \%$ \\
\hline $\begin{array}{l}\text { Share of low- wage workers } \\
\text { (2014) }\end{array}$ & $22.4 \%$ & $2.6 \%$ & $21.3 \%$ & $8.8 \%$ & $3.8 \%$ \\
\hline
\end{tabular}

Note: $\mathrm{X}=$ weak $; \mathrm{XX}=$ moderate $\mathrm{XXX}=$ strong.

Source: Visser (2016); Bosch and Lehndorff (2017); Eurostat, accessed 28 February 2018 at http://appsso. eurostat.ec.europa.eu/nui/show.do?dataset=earn_ses_publt\&lang=de. 
the workforce in their companies in Germany, with a voter participation rate of almost 80 per cent. Around 8400 of these works councillors are released from all work duties, with a further 1000 partially released. They are also trained for their duties as works councillors at their companies' cost, mainly in trade union training centres. This is several times more than all the full-time employees of the German trade unions. More than two-thirds of all works councillors and the vast majority of those released from their work duties are members of a trade union affiliated to the German Trade Union Confederation (DGB) (Greifenstein et al. 2011). This is several times more than all the full-time employees of the German trade union.

As a result of these good participatory standards, and despite their limited organisational power, the trade unions are able to determine the working and employment conditions of around 60 per cent of all employees. Their declining organisational power - trade union density fell from 36 per cent in 1991 to just 17.7 per cent in 2013 - and the broad swathes of the economy (particularly in the service sector) in which the works councils' and trade unions' writ no longer runs, have weakened the social partners' freedom to determine employment and working conditions autonomously, which explains the high share of low-wage workers. In those areas of the economy not covered by collective agreements, only the minimum legal standards apply.

In Sweden, the participatory standards are even stronger than in Germany; in addition to strong codetermination rights at establishment and company levels, the trade unions administer the unemployment insurance funds. This so-named 'Ghent system' creates strong incentives to become a union member and strengthens the unions' organisational power to such an extent that they are able to negotiate good wages for virtually all employees, making it unnecessary for the state to put in place supplementary protective standards, such as a statutory minimum wage or the extension of collective agreements. The United Kingdom, by contrast, is an example of a loosely regulated market economy, in which the state does not strengthen the trade unions' organisational power by means of participatory standards and sets only minimum standards by means of the minimum wage. In Belgium and France, virtually all collective agreements are declared generally binding; as a result, coverage by collective agreements is well above 90 per cent and the share of low-wage workers well below the German level. However, there are striking differences between the two countries. In Belgium, the state also strengthens the unions' organisational power through the Ghent system and codetermination at establishment level, so that they are able to negotiate wages significantly above the level of the minimum wage. In France, however, trade union density is only 8 per cent and participatory rights are very weak. As a result of the unions' weak organisational power, the collectively agreed pay scales tend to be raised mainly by the annual increases in the minimum wage. Table 5.1 shows that European industrial relations systems differ substantially. They may achieve similar results, such as low shares of low-wage earners, but with a different institutional architecture.

What has been demonstrated here, by taking the example of wage negotiations, could be extended to many other objects of negotiation, such as working time, job security, initial and continuing training, and protection of precarious workers. At the heart of the German industrial relations system, in which the unions are strong and firmly rooted in the workplace through the codetermination system, they are able to set their own standards at a level considerably higher than the statutory minimum and are able to take 
up new issues, such as lifelong learning and work-life balance. However, the expansion of areas of economic activity not covered by collective agreements, in which employers alone set the standards, has caused the German industrial relations system to become dualised. Wage undercutting has become so prevalent that the state has had to break with the tradition of free collective bargaining and introduce a statutory minimum wage. In other areas also, such as protection for precarious employees, the state is increasingly putting in place protective standards to combat the worst excesses of unregulated competition.

\section{ARE DOWNWARD TRENDS IN WAGES THE RIGHT WAY TO CONVERGENCE?}

\subsection{German Exports Impressive - Wages Not So Much}

Germany's international trade has specialised in high-value manufactured goods. After the Second World War, it developed into a country with chronic current account surpluses that had to be repeatedly reduced by regular revaluations of the Deutschmark. However, when the euro was introduced, this adjustment mechanism could no longer be used. Since then, the export surpluses that were contained temporarily during the 1990s by the increase in domestic demand following German reunification have been growing continuously. In 2016, they reached a new record high of 8.7 per cent of gross domestic product (GDP), exceeding the upper limit of 6 per cent set by the EU; currently, there is no foreseeable end to this growth. The weakness of the euro - a consequence of the crisis in many EU member states and the EU's austerity policy - has boosted Germany's export surpluses and German employment even further.

Germany's unsustainable current account surplus has given rise to criticism from the EU and the governments of many member states (Euroactiv 2013; Springford and Tilford 2014; Financial Times 2016). The EU regards a surplus of more than 6 per cent of GDP as a threat to stability and can even initiate legal proceedings. The criticism is levelled not at Germany's export successes, which cannot be restricted within a free trade area, but at the dampening of demand for imports to Germany as a result of inadequate wage increases and insufficient public investment. The obverse of the wage restraint and austerity adopted by the largest economy in the monetary union, it is argued, is the painful internal devaluations that the Troika has imposed on countries in deficit, such as Greece, Portugal and Spain, through large-scale interventions in national wage systems and government budgets.

Public investment, particularly in Germany's municipalities, has declined sharply since 2000 owing to the restrictive budgetary policy. Between 2003 and 2009, net public investment was even negative (Gornig et al. 2015, p. 1028). The stock of public capital declined and the infrastructure was literally being used until it 'wore out', as economists at the German Institute for Economic Research (DIW) put it (Gornig et al. 2015, p. 1023). Nominal wages per hour worked were rising significantly more slowly in Germany than in the euro zone as a whole, as well as in most other EU member states. Despite a strong economic upturn, they stagnated between 2004 and 2008, thus becoming detached from the general euro-zone trend. It was only after 2009 that they began to grow again (Figure 5.1). As a result of Germany's favourable track record in labour productivity, 

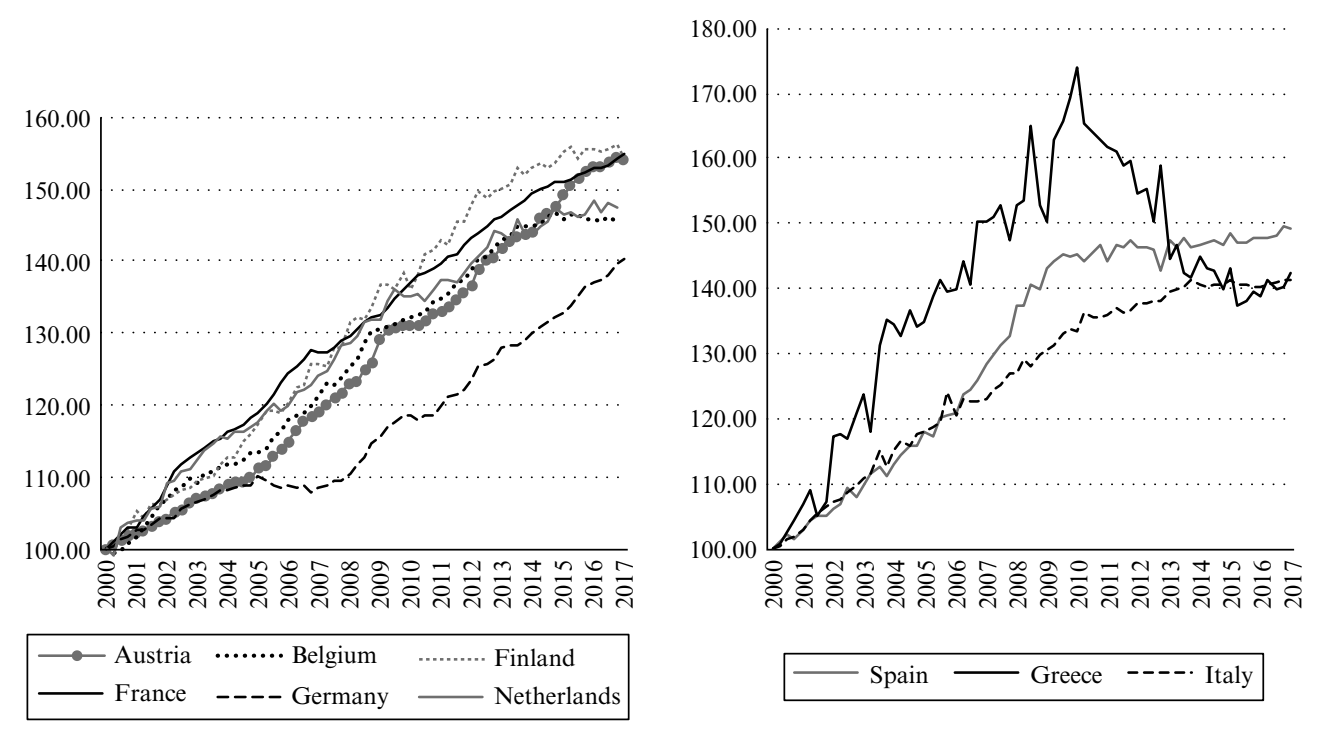

Note: $\quad$ Dotted line = euro zone; employee remuneration per hour; adjusted seasonally and by working day; national currency.

Source: Albu et al. (2017).

Figure 5.1 Evolution of employee remuneration in the euro zone and in selected EU member states, 2000-2017

the gap between developments in Europe as a whole and in Germany was even more pronounced when it came to unit labour costs. Between 2004 and 2008, unit labour costs in Germany fell, while they rose sharply in the rest of the euro zone, particularly in the south European countries subsequently hit by the economic and financial crisis (Figure 5.2).

Only a more detailed analysis of the structure and evolution of labour costs (Albu et al. 2017) per hour by industry can demonstrate the particularities of developments in Germany. They can be summarised as follows:

- At $€ 39$ per hour worked in the manufacturing sector, Germany is in fourth place in the EU and far above the average for the euro zone (€32.4).

- In no other EU member state are the differences in labour costs between manufacturing industry and private services as pronounced as in Germany. In the euro zone as a whole, the gap was $€ 3.6$; in Germany it was $€ 8.4$ and has increased even further since the introduction of the euro.

- In those sectors that have high levels of collective agreement coverage, such as manufacturing, energy, construction and financial services, labour cost increases have been considerably greater than in sectors with low coverage, such as retail and hospitality.

- Labour cost differences within industries and sectors have increased significantly, 

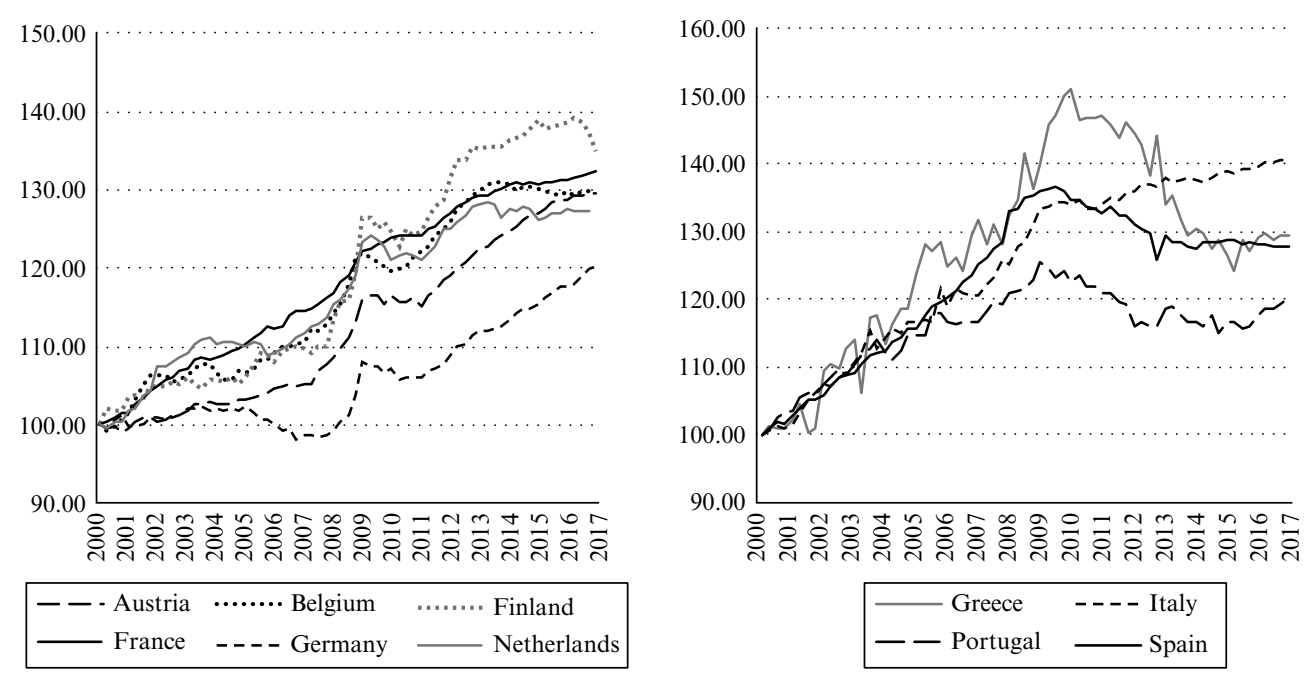

Note: $\quad$ Dotted line $=$ euro zone; dashed line $=$ European Central Bank inflationary target; employee remuneration per hour; adjusted seasonally and by working day; national currency.

Source: Albu et al. (2017).

Figure 5.2 Evolution of unit labour costs in national economies within the euro zone, 2000-2017

particularly between 2000 and 2008. The coefficients of variation for the evolution of labour costs during this period were 1.02 in the public services, 0.57 in private services and 0.38 in manufacturing. Between 2008 and 2016, the variations between the sectors were smaller than in the previous period.

- Input-output analyses of sales and deliveries between industries show that the share of services in pre-deliveries to German export industries was 31 per cent in 2012, which equates to a reduction in industrial labour costs of around $€ 4$.

- Overall, the differences between labour costs in various industries in the German labour market have increased considerably, particularly in private services. 'The differences of labour costs by industries (difference of $€ 34.3$ ) is almost as great as that between Denmark and Poland (difference of €35.4), which occupy first and twenty-fourth position, respectively, in the country rankings for labour costs in the private sector' (Albu et al. 2017: 10).

Thus the data show that labour and unit labour costs have evolved unequally not only within the EU but also within Germany itself. This raises two questions. To what extent can the wage restraint and the increasing variability in labour costs in Germany be explained by changes in industrial relations? What influence have these developments had on competitiveness and trade imbalances? 


\subsection{Wage Restraint on the Part of the Trade Unions or Political Erosion of the Collective Bargaining System?}

In some quarters, even the German trade unions have come under suspicion of acting in collusion with employers to enforce wage restraint in order to encourage job growth in Germany at the expense of other EU member states (Bofinger 2017). Thus in 1995, Klaus Zwickel, former head of IG Metall, proposed an Alliance for Jobs, Training and Competitiveness. At the time, IG Metall declared itself willing to forgo wage growth if new jobs were created in return, which in an export-orientated sector would have been equivalent to an internal devaluation (Wolf 2000). The model here was the 1982 Wassenaar agreement on wage restraint in the Netherlands, which is regarded as the start of the Dutch economic revival (Visser and Hemerijck 1997). Other commentators have been critical of productivity coalitions of well-protected insiders and companies that have tolerated the less favourable working and employment conditions endured by the less well-protected peripheral work forces or suppliers and have even actively campaigned against the introduction of a minimum wage (Carlin and Soskice 2009; Palier and Thelen 2010; Hassel 2014).

However, no agreements on wage cuts in exchange for new jobs were actually concluded. The IG Metall proposal was put forward more as a defensive response to an anticipated attack on the German collective bargaining system. However, the dominant neoliberal mainstream in economics and politics had long wanted more (Wolter 2016). Many companies had already withdrawn from the employers' associations and were no longer bound by collective agreements. This applied in particular to small and mediumsized firms, as well as to entire sectors, such as public services, where there had been 100 per cent coverage by collective agreement but which had been opened up to new providers by EU directives (post, railways, local transport, waste disposal, and so on). In the retail sector, employers had broken with the decades-old custom of agreeing to applications to declare collective agreements generally binding, which has led to a sharp reduction in coverage by collective agreement, from 100 per cent to the current level of significantly less than 50 per cent.

Around the beginning of the twenty-first century, in addition to the Hartz Acts, there were also calls for exit options from collective agreements to be created by abolishing the favourability principle ${ }^{1}$ and for it to be made easier to use cheaper temporary agency workers on a long-term basis. In 2003, the Schröder government threatened IG Metall with abolition of the favourability principle if the union did not agree to the inclusion of derogation clauses in collective agreements, which would permit company-level negotiations on proposed divergences from the industry-level agreement. In the 'Pforzheim Agreement' - named after the place where it was concluded - IG Metall reached agreement with the employers on derogation clauses, which have been widely used to cut wages and extend working times. The Hartz Acts made it easier for employers to use agency workers, while reductions in unemployment benefits increased the pressure on the unemployed to accept jobs in the low-wage sector.

As a consequence of these various measures, coverage by collective agreement, which in 1990 had still been around 85 per cent, fell sharply. In 2016, only 59 per cent of employees in western Germany were covered by collective agreements; in eastern Germany, where the trade unions have frequently been unable to gain a foothold in many 


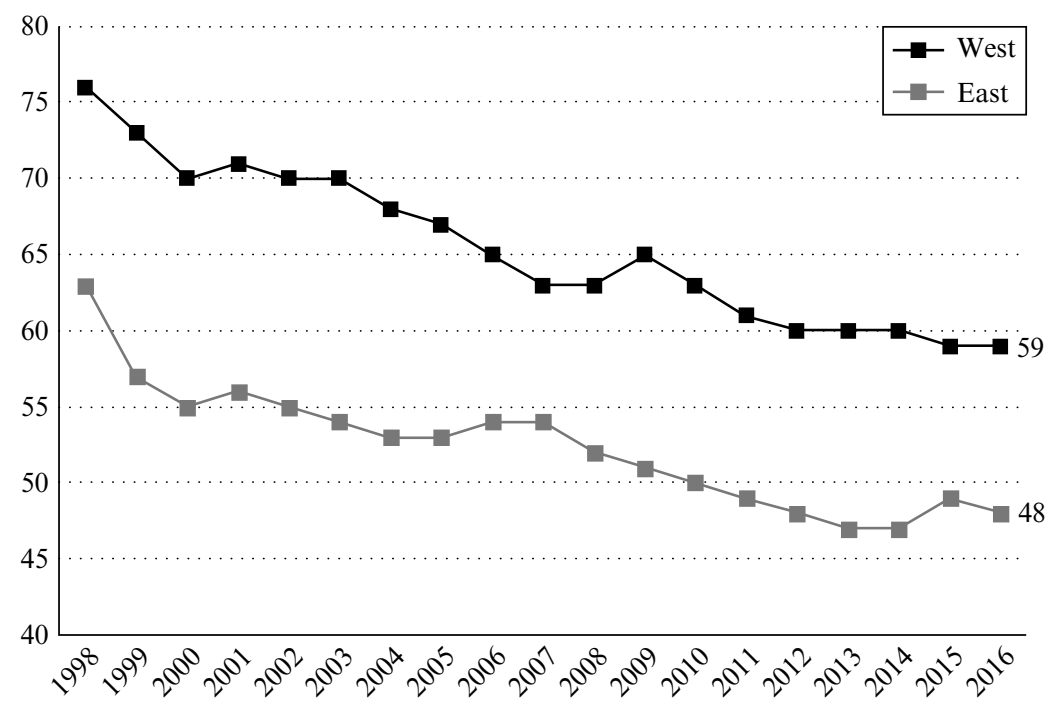

Source: WSI Tarifarchiv (WSI Collective Agreement archive; based on IAB Establishment Panel data), Hans-Boeckler Foundation, accessed 2 January 2019 at https://www.boeckler.de/36912.htm.

Figure 5.3 Evolution of coverage by collective agreement, West and East Germany, 1998-2016

of the companies that were newly founded after the breakup of the old state combines, the figure is only 47 per cent (Figure 5.3). In those sectors in which the unions are still strong, as in manufacturing industry, they have been able to negotiate good collective agreements since the year 2000. In contrast to earlier decades, however, the bargaining round is no longer governed by the 'convoy principle', according to which IG Metall took the lead and the less strongly unionised sectors used the agreements concluded in the metalworking and engineering industry as pattern agreements. As wage negotiations have fragmented, so the closed 'convoy' has broken up and the many 'small boats' that once constituted it are now moving at quite different speeds and in different directions. Employees no longer covered by collective agreements are floating backwards on the current and in some cases are having to accept considerable cuts in their nominal and real wages, unless their particular skills are in short supply, giving them stronger bargaining power (see section 4).

These developments, which were politically intended and not the result of the 'agentless' process of erosion so beloved of social scientists (see, for example, Streeck 2009), explain the increasing income inequality that is evident from the data. Some authors saw a breakup of earlier solidaristic political alliances whose aim was to include all categories of employee. Palier and Thelen (2010, p.125) argue: 'The stronger unions are joined in their opposition to a statutory minimum wage by the main employers' federations.' Hassel (2014) and Carlin and Soskice (2009) advance a similar argument, pointing to the emergence of new 'producer coalitions' between core workforces supposedly unaffected by deregulation and their employers, which are said to be dividing the trade union 
movement. The trade unions have not been the drivers but the driven in this development. They have been engaged in taking defensive measures. The manufacturing unions can at most be criticised for not having fought the Hartz Acts strongly enough, because they believed they would affect private services rather than their own sectors. As the number of agency workers in manufacturing industry began to increase rapidly, this turned out to be an error. Consequently, albeit with a few years' delay, and contrary to the assumptions of Carlin and Soskice (2009), Palier and Thelen (2010) and Hassel (2014), IG Metall also joined in the demands for a statutory minimum wage and organised successful campaigns to improve the pay of agency workers (for further details on this see Bosch 2018).

\subsection{German Wage Moderation and European Imbalances}

The lower than average increases in unit labour costs and growing current account surpluses in Germany are mirrored in the higher than average increases in unit labour costs and growing current account deficits in other EU member states. This symmetry makes it tempting to interpret these developments as causally related. Dustmann et al. (2014) argue, in a widely read article, that the transformation of Germany 'from sick man of Europe to economic superstar' is due above all to the restoration of price competitiveness through the decentralisation of pay bargaining.

However, competitiveness also depends on other, non-price factors, such as product quality and reliability. Even in the past, German exports always recovered quickly despite significant revaluations. The German Council of Economic Experts has calculated the net exposure to exports from China and Eastern Europe for the Western European regions in the period from 1991 to 2011. This value measures the difference in the increase in exports and imports in the sectors present in the various regions. The results show that most regions of Germany, in contrast to the United Kingdom, France, Spain and Italy, benefited from the trade relations (SVR 2017, p. 337). The ability of most German regions to withstand competition from price-sensitive imports from countries with lower wages can be explained by their specialisation in quality products of higher value.

Thus it cannot simply be assumed that wage restraint is the cause of Germany's export successes and, conversely, that the current account surpluses can be balanced out, largely through significantly higher wage increases. The complex interrelationships have recently been modelled by Horn et al. (2017). They examined the effects on the current account of an alternative wage policy between 2001 and 2015 that would have taken advantage of the scope for distribution opened up by productivity increases and the European Central Bank's target inflation rate. According to their calculations, the surplus would have fallen by only $€ 16.4$ billion in 2015 , a relatively modest reduction given that the total surplus for that year was $€ 220$ billion. Real net exports would, it is true, have fallen by $€ 55$ billion, but nominal exports would actually have risen as a result of price increases. However, it is important to note that government revenues would have increased significantly owing to higher wages and prices. Had these budget surpluses been spent, imports would have increased and the current account surplus would have been reduced by $€ 36.2$ billion. Thus, for these authors, the key to reducing Germany's current account surplus lies not solely in wage policy but also in an expansive national fiscal policy, which should be reflected above all in an increase in public investment. Somewhat resignedly, they conclude their report with the following observation: 
'However, Germany is not yet ready to take its financial policy in this direction' (Horn et al. 2017, p. 20).

The European Commission (EC) has come to similar conclusions in several studies of current account surpluses in the EU. In two large-scale studies on the surpluses, it concludes that, 'Overall there is no evidence that wage developments are at the root of the development' (EC 2012, p. 91) and '[n]otably, the impact of non-price factors has turned positive and its relative importance has grown since the beginning of the last decade and in some recent years has dominated price factors' (EC 2014, p. 90). Thus better coordination of wages policy can be only one element in a more comprehensive strategy for fostering the convergence of economic development in the euro zone that must also include public investment - particularly investment in innovation - which would make exports less price-sensitive. The Troika's fixation with cost reductions in southern and eastern Europe completely disregards these countries' real problem, which is their specialisation in price-sensitive products (Lehndorff 2015). Regaining competitiveness through diversification of production towards international market segments of high quality or high value-added products to break the vicious circle of low innovation-low productivity-low competitiveness, is the main challenge in these countries (Komninos et al. 2014).

\section{EROSION OF COLLECTIVE BARGAINING LEADING TO GROWING INCOME INEQUALITY}

The analysis of labour costs per hour worked, which are an important factor in determining unit labour costs, has already revealed the growing differentiation of labour costs in the various sectors of the German economy. This section focuses on the increasing inequality at the individual level before and after German reunification. Until reunification, real wages in the various deciles tracked the evolution of GDP per hour worked (Bosch and Kalina 2018).

Since then, three separate developments can be observed (Figure 5.4). First, since reunification, wages have become uncoupled from the evolution of GDP per hour worked, which has led to a decline in the wage share and an increase in income from profits. Secondly, until 1997, incomes in the various deciles were still rising in step with each other, which in the lower segment of the wage distribution in particular can be attributed to the strong income growth in eastern Germany. The reason for this strong growth lay in the agreements reached between unions and employers that sought to bring collectively agreed wages and working times in eastern Germany quickly into line with those in western Germany. Thirdly, since 1997, wages in the various deciles have been drifting apart. While real wages in the top decile (D9) have risen sharply up to the current boundary, the middle decile (D5) has sustained considerable real wage losses since 2003, which have not been made good in the recovery following the financial crisis. The bottom decile has been in freefall since 1998, reaching its lowest point in 2009. Such a strong decoupling of the lower income groups from the general evolution of pay was possible only because there was no minimum wage in Germany during this period that could have put a brake on this fall in wages in the sectors of the economy not covered by collective agreements.

The evolution of pay in Germany has been influenced by the catch-up process in eastern Germany; this was particularly the case at the beginning of the 1990s. Hourly 


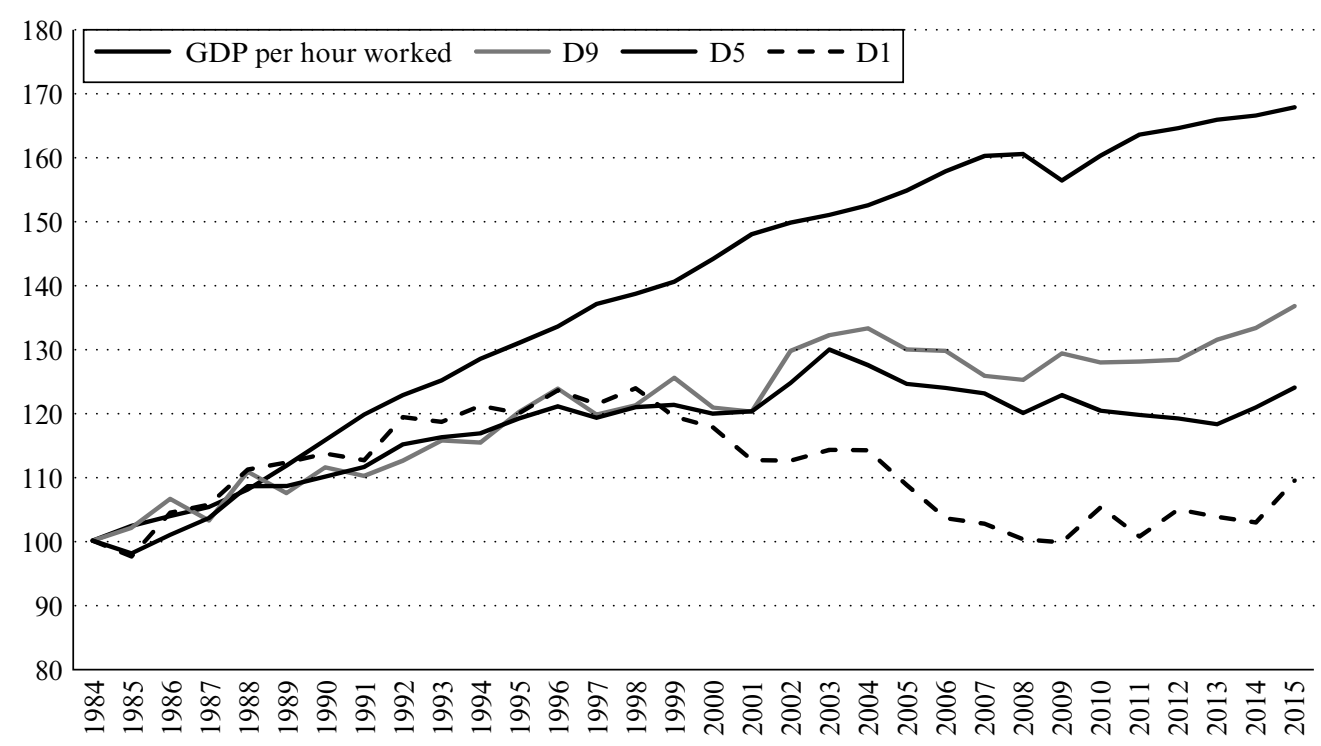

Source: Author's calculations using the Sozio-oekonomisches Panel (SOEP) v32.1; GDP per hour worked adjusted for prices, until 1991 West Germany, from 1992 onwards Germany as a whole: Statistisches Bundesamt, calculations by Thorsten Kalina (IAQ).

Figure 5.4 Evolution of real hourly wages by deciles, Germany, 1984-2015 (until 1991 West Germany) (all dependent employees), with GDP per hour worked as comparison

pay in eastern Germany rose from 54 per cent of the western German level in 1992 to around 70 per cent of that level in just two years. This process then slowed down and by 2012 the proportion had risen to 77 per cent (Bosch et al. 2014). In order to explain the differences in the evolution of the wage dynamic, it is helpful to consider the evolution of wage inequality in eastern and western Germany separately.

Before reunification until the mid-1990s the two decile ratios scarcely changed at all in West Germany, which reflects the stability of the wage-setting institutions in West Germany at the time (Figure 5.5). Subsequently, however, inequality increased sharply. The increase in the D5/D1 ratio between 1998 and 2008 was particularly pronounced, which points to the massive decline experienced by the lower income groups. While the D5/D1 ratio reached its zenith in 2009 and declined thereafter, the D9/D5 ratio is continuing to increase without any change in trend being detectable. In East Germany, which before reunification had a significantly more equal income distribution, income inequality rose sharply after reunification, starting from a very low level. While the D9/ D5 ratio has exceeded the West German level since the beginning of the twenty-first century, the D5/D1 ratio has not reached the West German level, which is probably due to the fact that coverage by collective agreement in East Germany is considerably lower than in the West and that, consequently, wages up to the fifth decile are severely compressed. Furthermore, the employers' associations have blocked any further alignment of wages and working times in eastern and western Germany, not least due to the low levels 


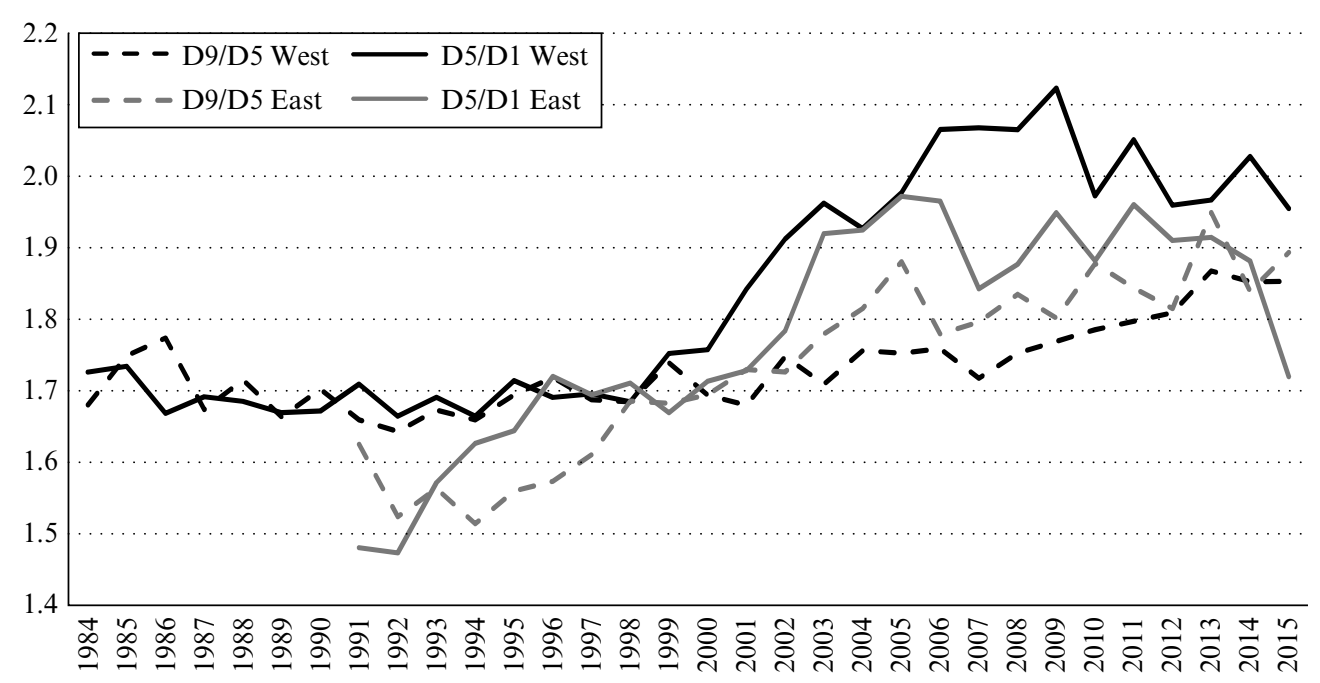

Note: * Working households have a head of household aged between 25 and 65 years and income from gainful employment.

Source: Calculations by Thorsten Kalina (IAQ) using the SOEP v32.1.

Figure 5.5 The inequality of hourly rates of pay over time, decile ratios (all dependent employees), West and East Germany, 1984-2015

of productivity in eastern Germany and their haemorrhaging of members in eastern German companies, which have increasingly preferred individual negotiations below the industry or sector level.

Inequality of market incomes rose in both eastern and western Germany, particularly in the years before the Hartz Acts, which came into force in 2004. However, our analyses do not support Fitzenberger's argument (Fitzenberger 2012) that the Hartz Acts had no significant influence on the wage distribution. The various decile ratios increased until the financial crisis, while at the same time the lowest wages (D1) declined sharply, which is all the more noteworthy because the German economy began to grow rapidly from 2004 onwards. Inequality normally declines and real wages normally rise in such growth periods.

It is evident from the shares of the middle income class (Vaughan-Whitehead 2016), with an equivalence-weighted income of between 60 and 200 per cent of median household income for the population as a whole, or just the economically active population, that this intermediate stratum remained extremely stable before and after redistribution up to the beginning or end of the 1990s, respectively (Figure 5.6). Owing to the increasing number of low-wage earners the share of the intermediate stratum has shrunk considerably since the beginning of the 1990s. ${ }^{2}$ Up to the end of the 1990s, the state was able to compensate for these losses in the intermediate stratum. Since then, however, the intermediate stratum has been eroding even after redistribution, a process for which there is currently no end in sight. As a result, Germany has developed one of the largest low-wage 


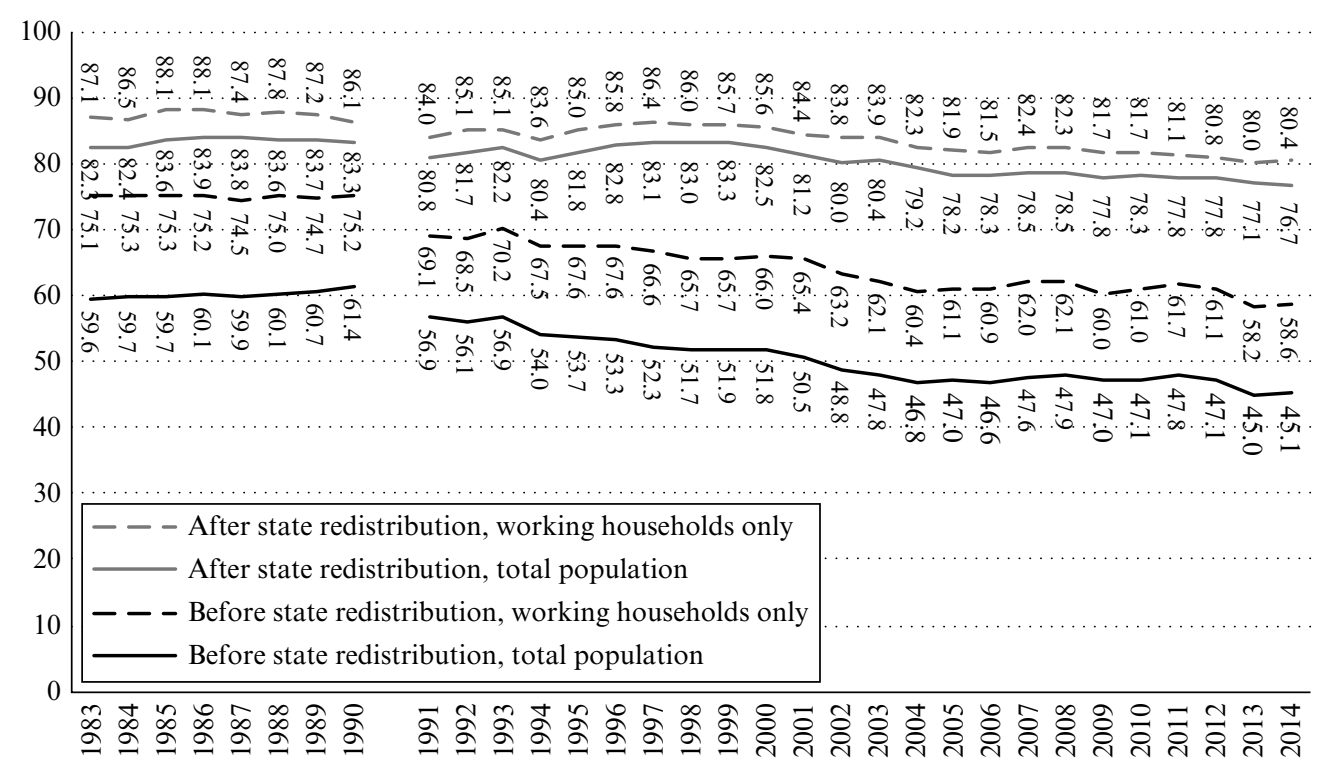

Note: * Working households have a head of household aged between 25 and 65 and income from gainful employment.

Source: Calculations by Thorsten Kalina (IAQ) using the SOEP v32.1.

Figure 5.6 Share of the middle income class (60-200 per cent of the equivalenceweighted median household income) before and after state redistribution, Germany, 1983-2014 (total population and working households only*)

sectors in Europe. In 2014, the share of low-wage workers in Germany, at 22.5 per cent, was significantly above the average in the euro zone, which stood at 15.9 per cent, and very much higher than in other developed welfare states in Europe, such as France (8.8 per cent) or Denmark (8.6 per cent). ${ }^{3}$

The qualifications profile of the individual income brackets has changed considerably. The share of low-skill workers in all brackets has fallen significantly. However, the upper income brackets have significantly higher shares of well-qualified individuals. Thus the share of university graduates in the upper income bracket was 58.5 per cent during 2011-13, compared with only 9.6 per cent in the lowest bracket, and the share of unskilled and semi-skilled workers was only 3.1 per cent, compared with 32.3 per cent in the lowest income bracket (Bosch and Kalina 2016, p. 212).

The growing inequality in households' equivalence-weighted market incomes can be explained by three developments. First, the share of low earners has risen, particularly in the lower income brackets, as a result of the decline in collective agreement coverage. Secondly, the share of income from capital has increased, particularly in the higher income brackets. Schmid and Adler (2013) show that the share of investment income recorded in the Sozio-oekonomisches Panel (SOEP) rose from 5-6 per cent of all income in 1990 to 9 per cent in 2007 and that this income was registered mainly in the top decile. 


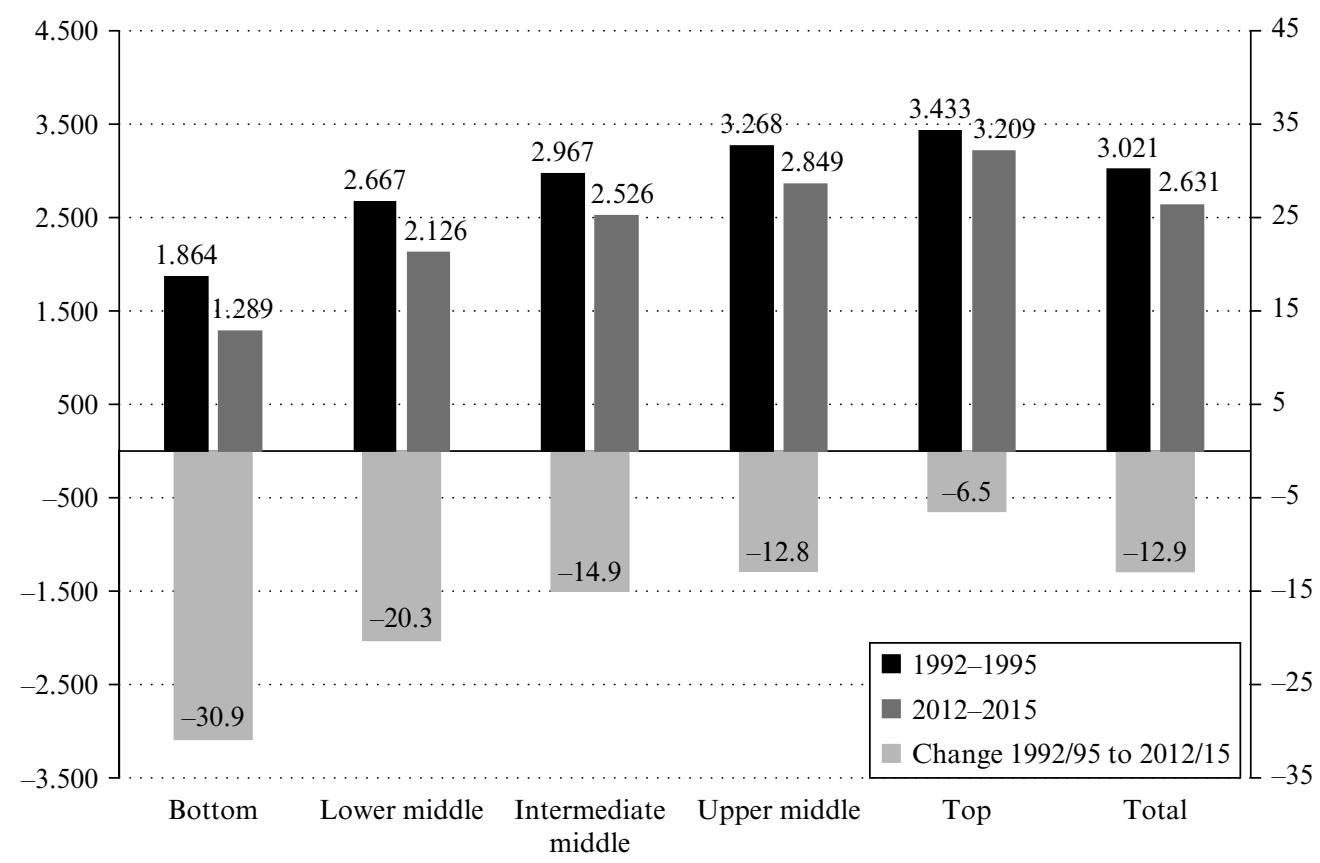

\footnotetext{
Notes:

* Annual working times include all paid hours (annual leave, paid public holidays and other leave, as well as paid sick days). The working times are summed in the case of multiple earner households.

** Working households have a head of household aged between 25 and 65 years as well as income from gainful employment.
}

Source: Calculations by Thorsten Kalina (IAQ) using the SOEP v32.

Figure 5.7 Annual working times* of working households** by income bracket (before state redistribution), Germany, 1992-2015 (percentage change)

Thirdly, and finally, working times have become polarised by income bracket. Figure 5.7 shows the evolution of working times in households with at least one earner; to improve the reliability of the data, the working-time data were pooled for four years in each case. According to these figures, the number of hours of paid work in households in the top income bracket in the period 2012-15 was, on average, almost 2000 hours per year greater than in households in the lowest income bracket. The volume of work declined in all income brackets, but the decrease in the bottom bracket, at 30.9 per cent, was considerably greater than in the top bracket, where it was only 6.5 per cent. The reason for this is the high share of individuals with multiple sources of income and of secondary earner households in the top income bracket, as well as the high share of singles and households with mini-jobbers in the bottom income bracket, both of which are categories with below-average volumes of work (cf. Bosch and Kalina 2016). Unfortunately, international comparative research is lacking in this area. However, the polarisation of working time in Germany is also particularly influenced by the strong financial incentives for 
marginal part-time work (mini-jobs). This trend is caused mainly by unilateral decisions of employers who decide on the number of working hours of newly recruited employees. In some industries the unions have tried to negotiate collective agreements on minimum standards for the working hours of part-timers (for example, a minimum of 20 hours per week), but in the service industries with the highest shares of mini-jobs they were too weak to manage this (see section 6).

\section{RE-REGULATION OF PRECARIOUS WORKING FORMS THROUGH COLLECTIVE AGREEMENTS}

\subsection{Increase in Atypical Employment}

In the wake of the structural collapse of the East German economy after reunification, the number of economically active individuals in Germany declined temporarily. However, these losses have now been more than compensated for. Between 2005 and 2007, the employed population grew by almost 5 million individuals and unemployment fell from its peak of almost 5 million in 2005 to 2.5 million in 2017 . However, the structure of employment changed as a result of the increase in the share of atypical employment forms.

The Federal Statistical Office now counts as standard employment not only permanent full-time employment but also part-time work of more than 20 hours per week. The factors in favour of this definition are that many part-time employment relationships over 20 hours per week are remunerated on the basis of the collectively agreed rates and are entered into voluntarily by the employees concerned; in some cases, moreover, they are only temporary. However, it attracts criticism because part-time work in Germany, in contrast to Sweden, has high scarring effects; that is, it is associated with lower wages and many other disadvantages later in individuals' working lives. However, those voicing this criticism also indicate that the differences between standard and atypical employment have been blurred to some extent by the erosion of the German wage system (Bosch 2017). Thus, in 2015, 14.3 per cent of full-time employees were low earners. This share is considerably lower than that of part-timers in insurable jobs (24.2 per cent) and of minijobbers who are low paid (74.4 per cent) (Kalina and Weinkopf 2017). However, owing to the declining rate of coverage by collective agreement, a permanent full-time employment contract has long since ceased to provide protection against bad employment and working conditions.

The share of atypical employment relationships in all dependent employment relationships rose from 15 per cent in 1991 to 23 per cent in 2016. If part-time employment relationships between 20 and 30 hours are included, the share in 2016 was 33 per cent (Figure 5.8). However, the share of atypical employment relationships is likely to be higher. In the micro-census, many mini-jobbers declared themselves to be economically inactive. Nor are contract workers posted from abroad included in the German employment statistics. Finally, many of the approximately 700000 solo self-employed workers are in the 'bogus self-employment' category, meaning they are in an employee-like dependent relationship with a single work provider but without the protection afforded by labour law and collective agreements. 

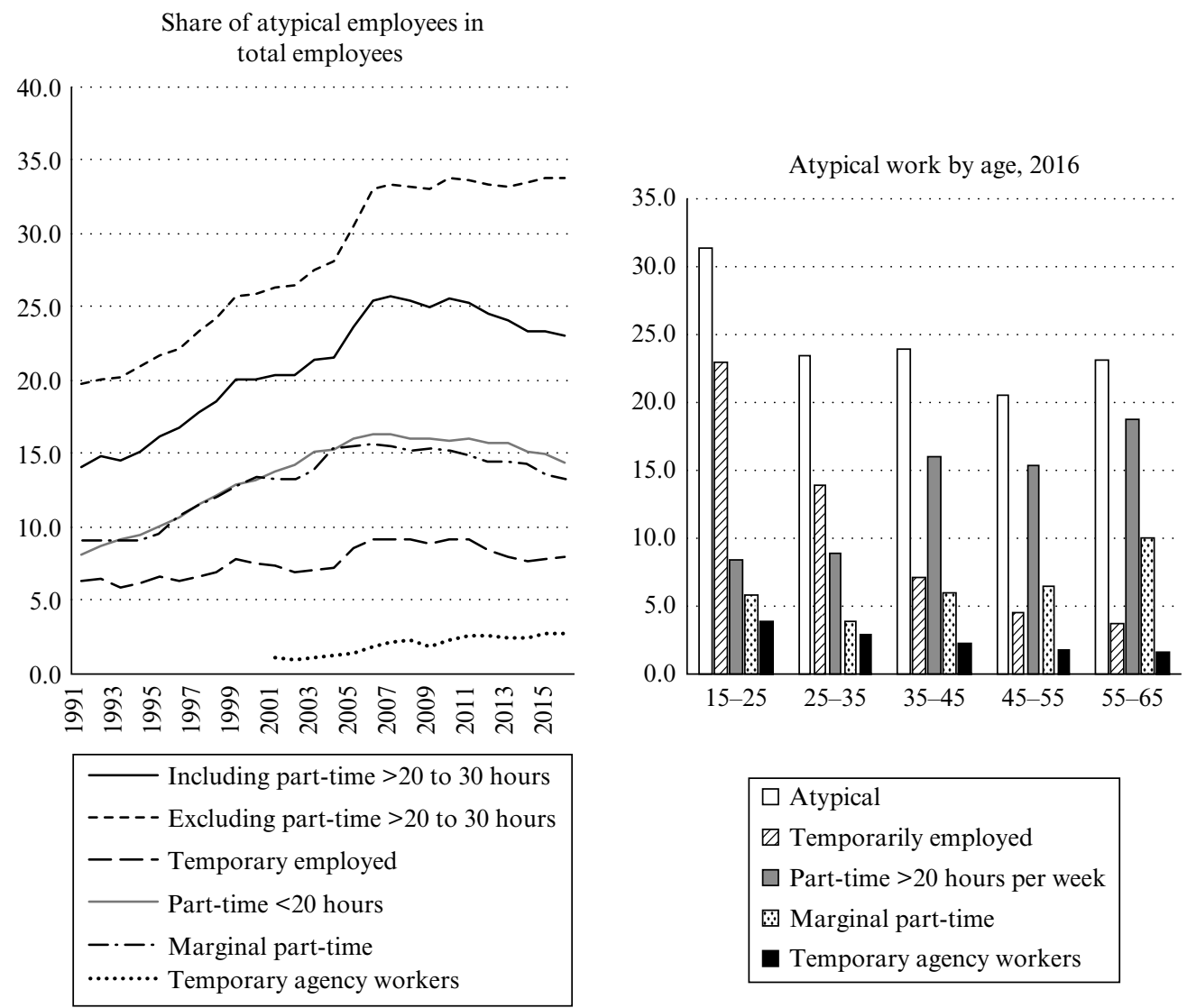

Source: SVR (2017, p. 366) (using micro-census data from the Federal Statistical Office).

Figure 5.8 Evolution of atypical employment forms, Germany, 1991-2016

Atypical work varies considerably with age, gender and qualification. Fixed-term contracts are concentrated among younger workers and signify an extension of the probationary period, which is often repeated several times. The same applies to temporary agency work, which is more widespread among younger workers. Part-time work for more than 20 hours per week, however, increases with age. This is characteristic of women's labour market trajectories, which tend to start with full-time employment before shifting during the child-rearing phase to part-time work, where they often remain. Marginal parttime work (mini-jobs) is spread more widely across the age groups (see also section 6).

Atypical employment forms are associated with high risks. The comprehensive literature in this area shows that atypical employees' wages are lower and their jobs at greater risk than those of standard employees. Furthermore, there are considerable shortcomings in the monitoring and enforcement of labour standards, and the transition into stable employment is more difficult than it was in the past (Jaehrling et al. 2017). The trade unions are making an effort to re-regulate the employment and working conditions 
of precarious employees. They have been successful only in those areas in which they have considerable bargaining power, however. In other areas, their only option is to re-regulate these employment relationships by influencing policy-makers, although here, too, any success depends on the political power relations.

These attempts to re-regulate precarious employment relationships through social dialogue and the exertion of political influence are now examined by taking the examples of temporary agency work and posted contract workers. Mini-jobs and part-time work are the subject of section 6 .

\subsection{Regulation of Temporary Agency Work}

Until 1982, temporary agency work was banned in Germany owing to bad experiences in the pre-war period. After temporary agency work was once again permitted, the maximum length of any one assignment was raised in stages from the original three months to two years, before all restrictions were abolished by the 2003 Hartz Acts. At the same time, the obligations on employers were relaxed by abolishing the prohibition on synchronisation; that is, matching the duration of the employment contract to that of the assignment. In the 2008 EU Directive on Temporary Agency Work (Directive 2008/104/EU) it is stated that: 'The basic working and employment conditions applicable to temporary agency workers should be at least those which would apply to such workers if they were recruited by the user undertaking to occupy the same job.'

The Schröder government transposed this principle of equal treatment into German law in 2003, but permitted divergent arrangements laid down in collective agreements. As a result, numerous 'wage dumping' agreements that removed the principle of equal treatment were concluded by the employer-friendly Christian trade unions. Temporary agency workers became cheap labour and the wage differentials for comparable jobs were as high as 50 per cent. Owing to these cost advantages, agency workers were deployed primarily in firms with good wages and collective agreement coverage, since it was there that the cost advantages were greatest.

The EU and many German legal experts took a very critical view of this development, which made exemption from the equal treatment principle the rule rather than the exception. In an expert report for the annual meeting of the German Legal Association, it was stated that 'a precondition for a derogation in compliance with the Directive is that the collectively agreed provisions shall diverge from the equal treatment requirement "with due regard for the overall protection of temporary agency workers"' (Waltermann 2010, p. 40). In the past decade, the trade unions have been able to point to infringements of the equal treatment requirement and the inadequate representativeness of the Christian trade unions in order to bring successful actions in the courts against the validity of most of the wage dumping agreements.

These legal successes have opened up a new space for trade union action. In 2012, the bottom pay grade in the collective agreement for the temporary agency sector was declared generally binding and became the sector's minimum wage. In 2018 the lowest rate of pay in the temporary agency sector was $€ 9.47$, which was slightly higher than the statutory minimum wage $(€ 8.84)$. The unions attempted to negotiate equal pay for temporary agency workers and to have it incorporated into collective agreements. However, they were successful only in the steel industry, because most works councils in 
that industry had already negotiated equal pay and incorporated it into company agreements. In other industries, such as the metalworking and chemical industries, industry supplements were negotiated. In the metalworking industry, for example, the collective agreement on temporary agency work concluded by the DGB provides for payment of a supplement of 15 per cent from the sixth week of an assignment, rising to 65 per cent up to the fifteenth month. In 2018 this takes the hourly rate for an unskilled assistant on the lowest pay grade from $€ 9.47$ to $€ 15.66$ by the fifteenth month of an assignment.

In 2016, under pressure from the trade unions, the Social Democratic Party (SPD) - in the last 'grand coalition' government - was able to push through new legislation on temporary agency work. According to this new legislation, the equal pay regulation comes into force from the ninth month of an assignment and the maximum length of any one assignment is limited to 18 months. Derogation from the equal pay regulation is permitted if industry supplements have been agreed from the sixth week of an assignment. Several unions have done this. Until 2016, the supplements were increased up to a maximum of 50 per cent after nine months. The additional increase to 65 per cent after 15 months mentioned in the preceding paragraph was agreed after the legislation was enacted. The collective agreement concluded by IG Metall also provides for an increase in the maximum length of an assignment to 48 months in exceptional cases, such as for projects or major investments (power station construction). In return, companies must offer to take agency workers on after 24 months and temporary agency work is not allowed for permanent positions.

Current figures show that, despite these improvements, the wages of temporary agency workers have not yet drawn level with those of comparable employees. Many companies are not covered by collective agreements and are not obliged to pay either the industry supplements or the collectively agreed rates that exceed the industry minimum wage. This explains the pay differentials that still persist. Thus an unskilled assistant working as an agency worker is paid on average $€ 1543$ per month, which is 28 per cent less than a direct employee doing a comparable job (€2133) (Bundesagentur für Arbeit 2017).

\subsection{Contract Workers: 'Islands of Foreign Labour Law'}

One of the essential characteristics of modern nation states is that their laws are rooted in their national territories and that this rootedness in turn defines the space within which national sovereignty applies. Even the great migratory flows made possible by the free mobility of labour within the EU have left the territorial principle intact. As they cross national borders, migrants move into a different legal system and become subject to the laws of the host country. Initial discrimination can be prevented by reference to Article 119 of the EU Treaty, which stipulates equal pay for equal work for men and women, and hence for foreigners and the local population alike. In the 1960s and 1970s, EU member states unanimously supported the goal of harmonising employment conditions while retaining the improvements that had been made in individual member states. ${ }^{4}$ Migration's potential for precipitating disputes over labour market policy was not to jeopardise the vision of a united Europe.

While labour law was governed by the territorial principle, competition law was governed largely by the country of origin principle, which the EU had been extending in stages since the beginning of the 1970s. In accordance with the freedom of services 
principle, companies can provide services for a limited period with their own workforce and on their own terms and conditions of employment in other member states. This freedom of services did not become of practical significance for the German labour market until the beginning of the 1990s, when companies in certain sectors, particularly construction, began to award large numbers of contracts for services to foreign companies. It soon became evident how far the territorial principle in labour law was being undermined by 'islands of foreign labour law' (Hanau 1997, p. 145). In contrast to the early years, the equal treatment principle no longer attracted sufficient support from EU members, since the new member states, with their varying levels of development, had made the EU increasingly diverse. The conflicts of interest became evident during the consultation on the 1996 Posted Workers Directive. While the target countries for posted workers generally voted for equal treatment in order to protect their labour standards, the less developed countries saw the provision of services using low-wage workers as an export opportunity that they did not wish to pass up. A further factor was the increasing dominance of free-market thinking that caused even the governments of a number of target countries, such as the United Kingdom, to oppose all regulation of the labour market. In the end, the 1996 directive merely laid down minimum conditions and left it up to the nation states to regulate equal treatment at national level. However, in the Laval Quartet - four decisions by the Court of Justice of the European Union that have had far-reaching implications - nation states' room for manoeuvre was considerably reduced. The court took the view that the equal treatment of contract workers conflicted with the basic economic freedom to provide services in other member states; consequently, only minimum regulations that were 'proportionate' were permitted. Furthermore, the judges saw only individuals as worthy of protection. The right to the collective representation of interests and collective agreements, however, was not seen as a good worthy of protection, a decision that attributed to it less value than was attributed to the basic economic freedoms, unless the collective agreements were declared generally binding by the state (Bosch and Weinkopf 2013a). One of the court's judgments, the Rueffert judgment, related to Germany. The awarding of public contracts for construction projects in the state of Lower Saxony only to companies covered by the industry collective agreement was declared unlawful, because the collective agreement had not been declared generally binding and the conditions to be laid down exceeded the minimum level. This judgment even gave foreign contractor companies an advantage over German companies bound by collective agreements, which now had no chance of competing with foreign contractor companies. To prevent discrimination against foreigners, discrimination against local populations was condoned and collective agreements implicitly interpreted as a barrier to trade.

In Germany's autonomous industrial relations system, in which protective standards - such as collective agreements that have been declared generally binding - were the exception (Table 5.1), these decisions by the Court of Justice of the European Union opened the way for foreign contract companies to systematically undercut collectively agreed rates of pay. As a result, Germany became the most important target country in the EU for the posting of foreign contract workers, mainly from eastern Europe, as German employers sought to cut wage costs. Postings to Germany from other western European countries, which tended to be based more on the skills provided by the posting companies and the quality of their services, played only a minor role. 
Table 5.2 Number of Al certificates for postings in the EU and selected countries, by country of origin and sending country and region, 2015 (percentage)

\begin{tabular}{lcccc}
\hline Region of origin & EU & Germany & France & Belgium \\
\hline & $\mathrm{n}=1495307$ & $\mathrm{n}=218006$ & $\mathrm{n}=130468$ & $\mathrm{n}=63467$ \\
Western Europe & 81.9 & 78.2 & 69.8 & 91.9 \\
Southern Europe & 9.1 & 12.5 & 21.9 & 5.7 \\
Eastern Europe & 5.8 & 9.2 & 8.4 & 2.4 \\
& $\mathrm{n}=1495307$ & $\mathrm{n}=418908$ & $\mathrm{n}=177674$ & $\mathrm{n}=156556$ \\
Western Europe & 40.6 & 17.2 & 36.6 & 56.2 \\
Southern Europe & 15.9 & 6.3 & 39.4 & 12.0 \\
Eastern Europe & 43.6 & 76.5 & 24.0 & 31.8 \\
\hline
\end{tabular}

Source: EC (2016a).

There are no accurate statistics on the volume of postings within the EU. As an alternative, the EC falls back on analysis of the number of notifiable A1 certificates, which confirm that posted workers remain in their home country's social security scheme. ${ }^{5}$ In 2015, 2.05 million A1 certificates were issued in the EU, of which 240862 (11.7 per cent) recorded Germany as the country of origin but almost twice as many (463176 or 22.6 per cent) gave Germany as the country of destination. Some of the certificates were issued for one or more countries. Analysis of the 1495307 certificates issued for a specific country of destination shows that Germany is by far the most important receiving country for postings in the EU (Table 5.2). This reflects not only the size of the German economy, but also its geographical proximity to the major eastern European sending countries (Poland, Slovakia, Slovenia and Hungary). Germany sends contract workers mainly to western Europe (78.2 per cent of the A1 certificates), whereas 76.5 per cent of the contract workers in Germany come from eastern Europe. The regional distribution of postings abroad is similar in France and Belgium, but the share of contract workers from eastern Europe is considerably lower than in Germany. In addition to the greater geographical distance, the main reason for this is the inclusive wage systems (Table 5.1). In France and Belgium, collective agreements that have been declared generally binding also apply to foreign contract workers, so that wage cost advantages arise only in the event of non-compliance with protective regulations or the abolition of all seniority payments.

In the German wage system there were no lower limits on wages for foreign contract workers prior to the introduction of the statutory minimum wage. Only in the main construction trades had an industry minimum wage been introduced - as early as 1996 although in contrast to France and Germany the entire pay scale had not been declared generally binding. As a result of the large-scale use of foreign contract workers, in some cases employed on hourly rates of only $€ 3$ to $€ 4$, some industries, such as the German meat processing industry for example, became low-cost suppliers within Europe. Cuttingedge technologies, a good infrastructure and efficient logistics were combined with the working and employment conditions of an underdeveloped country. The rapid increase in German meat exports and the relocation to Germany of foreign meat-processing companies, such as Danish Crown from high-wage Denmark, can be attributed to these massive distortions of competition (Weinkopf and Hüttenhoff 2017). 
Legal postings are also frequently used as an opportunity to enter a market and as a smokescreen for illegal postings, whether in the form of unnotified postings or foreign workers falsely claiming to be self-employed (Bosch and Weinkopf 2013a). It is estimated that for every legal posting there is a further illegal one, which means that postings are of greater significance for the labour market than the European Commission's calculations would indicate (EC 2016a). Employees and trade unions in the sectors most affected by postings - such as the construction and meat-processing industries - have long since lost their belief in a common European social model. This was clearly acknowledged by Monti in his 2010 report on the single market, in which he declared with great restraint that 'The revival of this divide has the potential to alienate from the Single Market and the EU a segment of public opinion, workers' movements and trade unions, which has been over time a key supporter of economic integration' (Monti 2010, p. 68).

\section{CASE STUDY 1: WORKING TIMES - NEGOTIATED BY SOCIAL PARTNERS OR DETERMINED UNILATERALLY BY EMPLOYERS?}

Working times can be determined unilaterally by employers, mandated by legislation or negotiated by the social partners (Berg et al. 2014). Hybrid forms of these working-time configurations can be found in most countries, although one form usually dominates, such as the unilateral configuration in the United States, the mandated configuration in France and the negotiated configuration in Sweden. As with wage-bargaining, until 1990 Germany was an example of a negotiated working-time configuration. As a result of declining collective agreement coverage and the growing importance of statutory minimum standards, Germany has now developed into a hybrid type, albeit one in which the standards laid down in collective agreements still exert considerable influence for full-time employees at least, in contrast to the situation with wage-bargaining.

The German Working Time Act lays down a broad framework for weekly working time. A regular weekly working time of 48 hours is legally possible. It can be increased to 60 hours only if an average of eight hours per day is not exceeded within a period of six calendar months. Most employees are a long way from these upper limits. The average agreed weekly working time of 38 hours is far below the legal ceiling. This figure has risen slightly since the mid-1990s, when the trade union policy of further weekly working time reductions came to an end following the introduction of the 35-hour week in the metalworking industry. There are two reasons for this rise. First, the inclusion of derogation clauses in collective agreements made it possible to agree temporary increases in working times. Secondly, the decline in collective agreement coverage led to an increasing number of companies raising weekly working times again to 40 hours and more. The agreed annual holiday entitlement is 30 days. In companies not covered by collective agreements, however, the minimum of 20 days' annual holiday stipulated in the European Working Time Directive often applies. When the Directive was first enacted, it was of little significance for working time in Germany; today, however, it has become an important last line of defence in many areas of the economy.

Normal weekly working times for men, which also include overtime, diverge markedly in some respects from the European average (Figure 5.9). First, the share of men who 


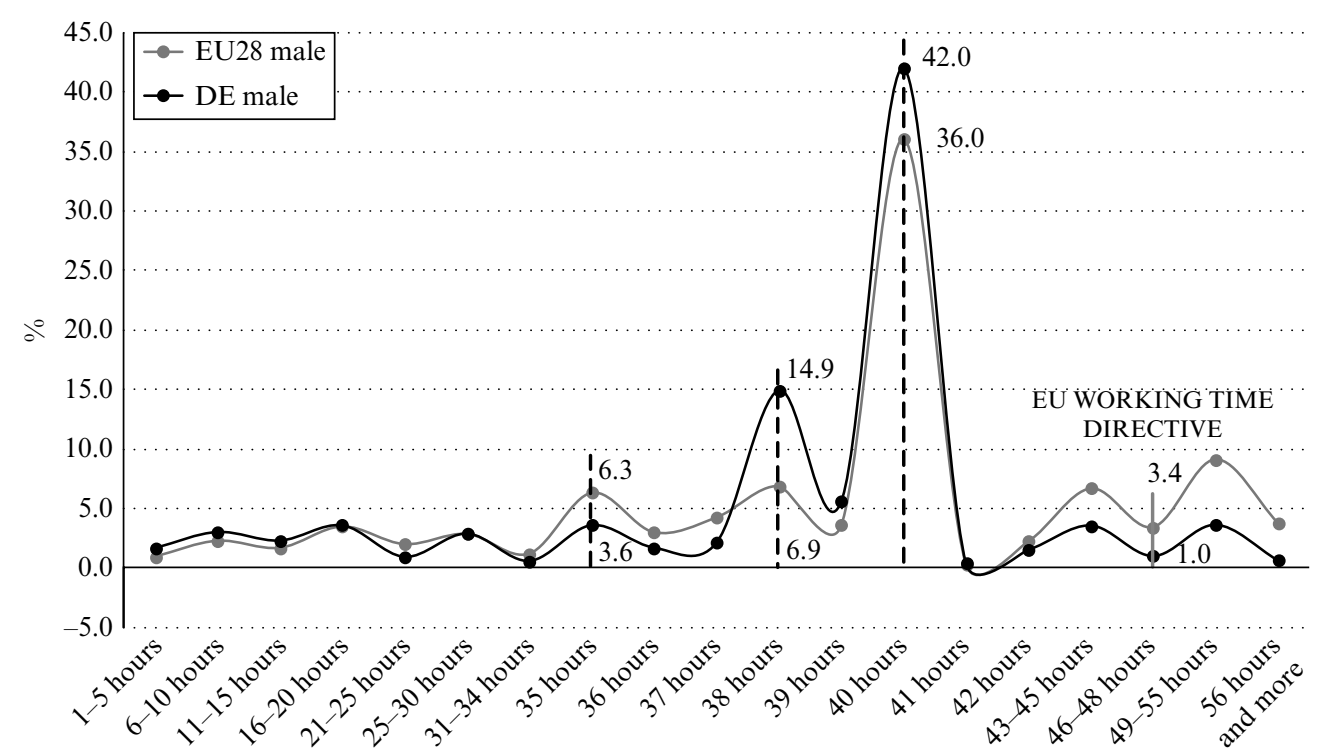

Source: Eurostat, Labour Force Survey 2015.

Figure 5.9 Distribution of normal weekly working times for men, EU28 and Germany, 2015 (percentage)

work more than 42 hours per week is significantly lower than the European average. There are three reasons for this. The first is that in many companies the trade unions have succeeded in reducing the level of overtime in order to make jobs available for younger people, particularly trainees. Secondly, virtually all collective agreements now provide for a more variable distribution of working time over the year or even the product cycle through the use of working-time accounts, so that fluctuations in demand can be evened out by varying working times. Thirdly, many companies have been able to cut down on expensive overtime by adopting more efficient processes, thereby reducing wage costs.

Furthermore, the share of employees whose usual working times are between 35 and 37 hours is below the EU average. This - as well as the increase since 1995 in the share of employees working 40 hours per week - clearly demonstrates the effects of the derogation clauses and the decline in collective agreement coverage. Confirmation is provided by a major survey carried out in 2017 by IG Metall, in which 681000 employees within its area of organisation (metalworking and electrical engineering industry, textiles, timber and plastics) were questioned. The results show that in 2017 only 47.8 per cent of respondents still had an agreed working time of 35 hours per week, compared with 50.5 per cent in 2013 (IG Metall 2017, p. 21). As in the rest of the EU, few men in Germany work parttime. Those who do are predominantly younger men combining work and education, unemployed individuals who are allowed to work a few hours in order to top up their benefits and older men working to top up their pensions. 


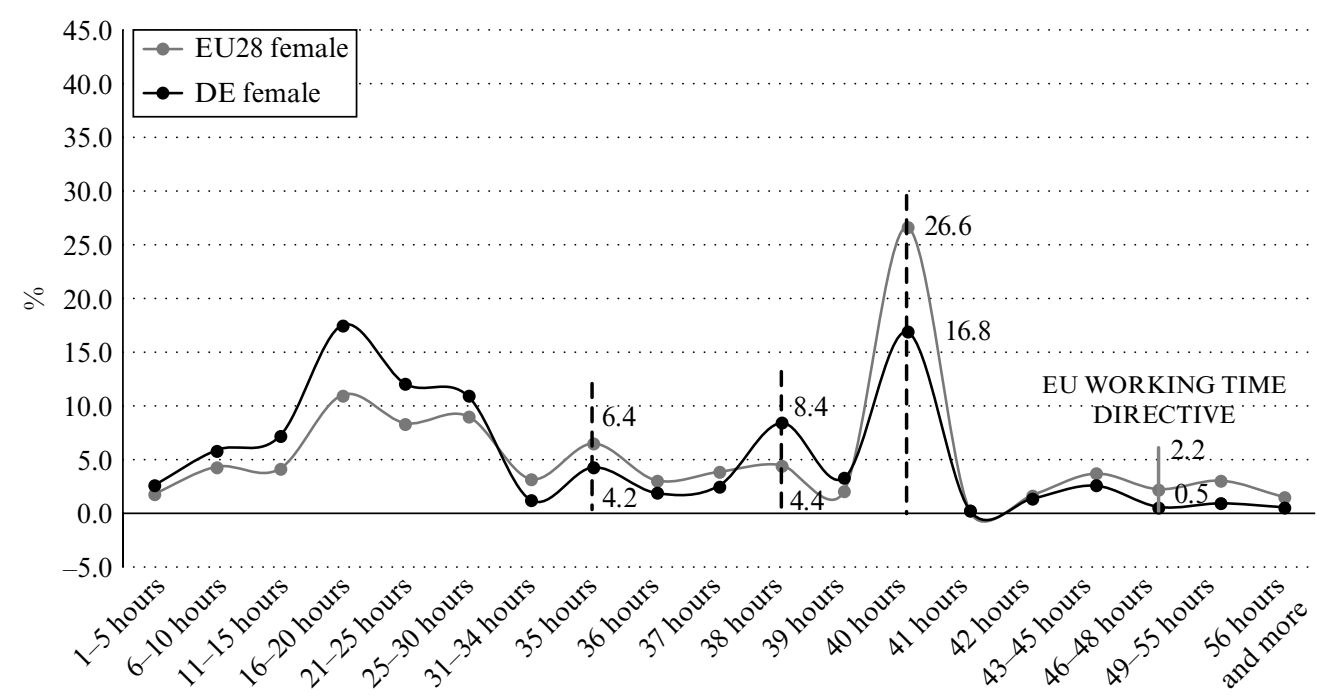

Source: Eurostat.

Figure 5.10 Distribution of women's usual weekly working times, EU28 and Germany, 2015 (percentage)

The picture for women is different (Figure 5.10). Two things are particularly striking. First, higher shares of women have very short working times in Germany than in the rest of the EU and, secondly, there is a smaller share of full-time women employees working around 40 hours per week. For the same reasons as men, fewer women in Germany work excessively long hours than the average across the EU.

In the past, the high share of women with short weekly working times arose largely out of the dominance of the traditional family model. Half-day school, nurseries that often closed at midday and the almost complete absence of care facilities for children under 3 years of age meant that women with children had little time for paid work. From 2003 onwards, when the first programme to develop all-day schools was launched, German family policy started to undergo radical change. On 1 January 2007, following the Swedish model, paid parental leave of 14 months following on from maternity leave was introduced, and since August 2013 every child aged between 1 and 3 years of age has had a legal entitlement to a nursery place. The work-life balance for families with children has improved significantly, which explains the sharp increase in the employment rate for women aged 20-64 by 13.2 percentage points from 61.3 per cent in 2005 to 75.5 in 2016. Germany's female employment rate is in the upper part of the range within the EU. However, owing to the high share of marginal part-time jobs, the difference between the employment rate in absolute figures and the employment rate in full-time equivalents is higher than in any other member state, apart from the Netherlands (Figure 5.11). Expressed in full-time equivalents, the increase from 48.3 per cent in 2005 to 58.1 per cent in 2016 was only 9.8 percentage points, which is attributable primarily to a further increase in part-time work (EC 2015a, 2017a). 


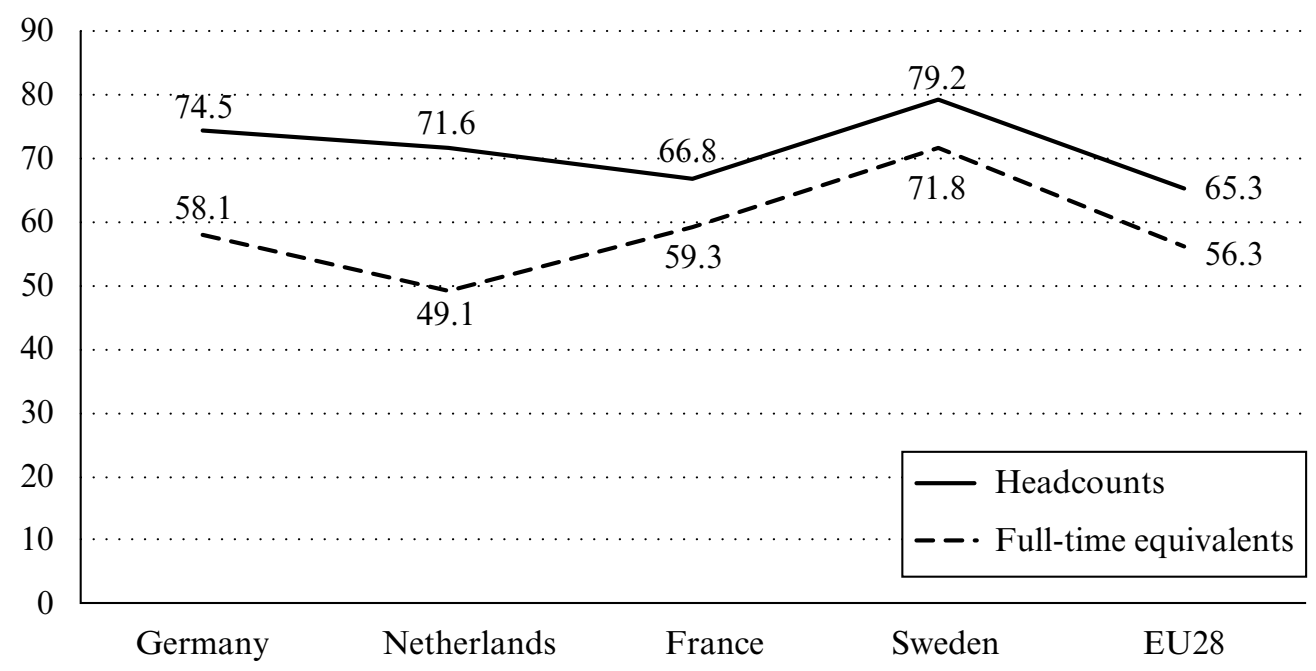

Source: EC (2017, statistical annex).

Figure 5.11 Employment rate for women (aged 20-64) in absolute figures and full-time equivalents, EU and selected member states, 2016 (percentage)

The strong financial incentives in the conservative family model for second earners in a household to work just a few hours or not at all come into play here. The joint taxation of married couples means that any increase in the woman's working time is subject to high marginal tax rates. In addition, there are considerable incentives to take a tax-exempt mini-job. 'Mini-jobbers' can earn up to $€ 450$ per month or up to $€ 5400$ per year free of tax. A spouse's derived entitlement to health insurance also remains in place. The marginal tax rate for a married woman (and occasionally for a married man) who moves from a mini-job to a job liable for social security contributions is extraordinarily high: once monthly earnings exceed the $€ 450$ threshold by just $€ 1$, not only do employer's social insurance contributions have to be paid in full, but the entire part-time income is also liable for income tax. The $€ 450$ threshold, which the statutory minimum wage also turned into an upper limit on working time of around 12 hours per week, explains the peak in women's working times at the bottom end of the distribution. This artificial threshold rations the labour supply of women who, according to all the working-time surveys, would like to work significantly longer hours.

It is also in many companies' interest to hold fast to this upper limit, but for a completely different reason. For employers, mini-jobs are more expensive than insurable parttime work because they have to pay a flat-rate levy of 30 per cent. Hanau (2006) describes mini-jobs as a puzzle. 'In actual fact, it is baffling what might induce employers to hire workers whose employment is associated with significantly increased non-wage labour costs' (Hanau 2006, p. 809). This puzzle can be solved only by considering mini-jobbers' actual employment conditions. Extensive research in this area has shown that in practice mini-jobbers are treated unequally. Their hourly rate of pay is often lower than that of employees in comparable insurable jobs and they are usually paid only for the hours 
worked; they do not receive the paid holidays or sick leave to which they are entitled. The most recent data is to be found in an IAB (Institute for Employment Research) survey of employees and companies carried out in 2015. According to the survey data, the average hourly rate of pay for mini-jobbers was just $€ 9.30$, compared with $€ 16.70$ for part-timers in insurable jobs, $€ 18.30$ for full-timers on fixed-term contracts and $€ 21.00$ for permanent full-time employees. Furthermore, more than half of all mini-jobbers earn less than $€ 8.50$ (Fischer et al. 2015, p. 56f) and, at 77.4 per cent in 2015, they also have the highest share of low-wage earners of all employment forms (Kalina and Weinkopf 2017).

The Organisation for Economic Co-operation and Development (OECD) and the EC exhorted Germany on several occasions in the 2016 European Semester to reduce the high marginal tax rates for second earners; German policy-makers have yet to respond. ${ }^{6}$ The trade unions have tried on many occasions to reduce the amount of marginal parttime work but with only moderate success, since mini-jobs are a crucial element of the business models in many service industries, such as retailing, cleaning or catering. The best agreements were concluded by trade unions in sectors in which mini-jobs play only a marginal role, such as in the metalworking industry. Thus according to the collective agreement negotiated by IG Metall in North Rhine-Westphalia, all new part-timers must be liable for social insurance contributions. In a small number of collective agreements, such as that in the North Rhine-Westphalia retail/wholesale trade, the service sector union ver.di succeeded in pushing through a minimum weekly working of 20 hours for part-time employees. However, derogations are possible by agreement, which is the rule in practice. In North Rhine-Westphalia's retail sector, employees who for 17 weeks work more hours than the agreed working time can also request an increase in their contractual working time up to the average level for the previous 17 weeks. The trade union official responsible for the retail sector said that employees generally accept the shorter working times they are offered in order to secure the job. However, when they have been employed for some time and have gone beyond the notice period, some of them take advantage of the opportunities to increase their contractual working time. However, she also reported that ver.di has not succeeded in extending this arrangement to the retail sector nationally.

Improvement of the work-life balance has become a key issue for both the legislature and trade union collective bargaining policy in recent years. In 2001, full-time workers in companies with more than 15 employees were given the right to switch from full-time to part-time employment. A right to revert to full-time work in companies with more than 45 employees is included in the new grand coalition agreement. Also, instead of further across-the-board reductions in working time, trade unions are now negotiating opportunities for temporary working-time reductions over the life course. The railway and transport union negotiated a pay rise of 2.6 per cent for employees of German Railways for 2017, which employees can take either in the form of an hour's less work (38 instead of 39 hours) or an additional six days' leave per year. In February 2018, IG Metall negotiated an arrangement whereby employees can temporarily reduce their working time to 28 hours per week for a maximum of two years and an increase in holiday pay of 27 per cent of a month's salary, which can also be taken by parents, carers or shift workers in the form of eight days off in the course of a year. These two agreements indicate a paradigm shift in trade union working-time policy towards support for more individual options. This policy becomes particularly powerful in combination with the 
new legal opportunities for individuals to change their working time. The key provision here is the right to return to full-time work, which can prevent employees from being permanently consigned to part-time work, with all the severe scarring effects this form of working time can engender.

Summing up, the social partners were able to negotiate innovative collective agreements on working hours that improved the work-life balance, as well as company competiveness. The new parental leave scheme as well as the high investments in childcare and all-day schools have helped to increase women's participation in employment. However, many women are discouraged from moving into jobs above the mini-job threshold, which explains the very high share of marginal part-timers in Germany.

\section{CASE STUDY 2: STRONG ROLE OF SOCIAL PARTNERS IN THE MINIMUM WAGE}

On 1 January 2015, a statutory minimum wage of $€ 8.50$ was introduced for the first time in Germany; two years later, on 1 January 2017, it was raised to $€ 8.84$. This increase was decided by the Minimum Wage Commission, whose members include three representatives from the trade unions and three from the employers' side, together with two academic experts proposed by the social partners. In deciding on the first increase in the minimum wage, the Minimum Wage Commission followed the formula stipulated in the Minimum Wage Act, namely, that the minimum wage should be raised every two years in line with the average increases in collectively negotiated rates of pay over the same period. At the parliamentary hearing on the draft bill, the social partners acted in concert to insist on this arrangement. In doing so, they were following the tradition of free collective bargaining and rejecting any political intervention in wage-setting, so that it would be their pay policy that set the benchmark for the biennial increases in the minimum wage. Deviations from this formula can be agreed only if there is a two-thirds majority in favour within the Minimum Wage Commission, which is likely only in exceptional situations, such as in another financial crisis.

Systematic evaluations using difference-in-difference methods are not yet available. Nevertheless, descriptive statistics show that the slump in employment predicted by mainstream economists has not happened. The rise in employment has actually accelerated further following the introduction of the minimum wage. Thus between 2014 and 2017 the number of dependent employees rose by 1.7 million, compared with 1.1 million between 2011 and 2014 (Hohlfeld et al. 2017, p. 8).

Moreover, there have been considerable increases in income in the lower deciles of income distribution. Comparison of the wage increases between 2014 and 2016 with those in earlier years shows that between 1998 and 2014 wages in the bottom two deciles rose at a rate of approximately 1 per cent per year, considerably less than those in deciles 8 to 10 , which rose on average by 4 per cent per year. Between 2014 and 2016, as a result of the new minimum, the evolution of wages was reversed. In the bottom decile, the increases even reached 15 per cent (Figure 5.11). Between 2014 and 2016, wage increases averaged 4.8 per cent. Following the introduction of the minimum wage, women $(6.8$ per cent), mini-jobbers (9.2 per cent), employees without vocational training (7.2 per cent), employees in companies with between five and nine employees (13.4 per cent) and 
foreigners (9.3 per cent) received considerably more (Burauel et al. 2017, p. 1121). Rises for workers in the very smallest companies, with up to five employees, however, were below average at only 3.2 per cent, which indicates considerable compliance problems in this area. These wage increases corrected some of the worst distortions of the income distribution at the lower end. The share of low-wage earners in Germany, however, remains high and above the EU average. One reason for this is that the minimum wage, as in United Kingdom, with a relative value on the Kaitz index ${ }^{7}$ of 48 per cent (United Kingdom 49 per cent) is set lower than, for example, in France (62 per cent) or the Netherlands (60 per cent) (Schulten 2017). The second reason is the still high level of non-compliance.

In 2016, around 1.8 million people entitled to the minimum wage were paid less than $€ 8.50$ per hour. The share of non-compliance is particularly high in mini-jobs (43.3 per cent), among temporary employees (19.2 per cent) and employees without vocational qualifications (15.6 per cent), and in firms with fewer than five employees (33.3 per cent) and firms with between five and nine employees (23.6 per cent) (Burauel et al. 2017, p. 1120). Even the above-average pay rises for some of these groups of workers were not sufficient to take all workers in these groups above the minimum wage threshold. This shows just how far the German wage structure had unravelled before the introduction of the minimum wage. Case studies show that most companies now have a clean 'paper trail' and pay at least $€ 8.50$ for the contractual working time. However, additional hours worked beyond the contractual working time are often not paid, particularly in very small companies without works councils whose employees have little bargaining power. Also, as previously mentioned, mini-jobbers also tend to miss out on paid holidays and sick leave. Furthermore, the number of inspections has declined. The German Customs Authority's Undeclared Work Enforcement Unit (Finanzkontrolle Schwarzarbeit), which is responsible for monitoring compliance with the minimum wage, inspected 63000 companies in 2014. That number fell by more than a third to 4074 in 2015 and 43627 in 2016. It was not until 2017 that the number of inspections began to rise again (Deutscher Bundestag 2017). The official reason given was that many customs officials had been temporarily redeployed to assist with the refugee crisis, where there was an acute shortage of personnel. However, it had almost certainly been decided as well that companies should be given time to adapt to the minimum wage. Whatever the reason, there were hardly any inspections in the first four months of 2015.

Figure 5.12 shows that wages rose more sharply than previously, right into the sixth decile, which indicates possible ripple effects. When the wages of the low-paid workers in a company rise, the employer often raises the pay of the more highly skilled employees as well, in order to maintain motivation and prevent them from leaving. In countries with high levels of collective agreement coverage, however, such ripple effects are institutionalised when wages are renegotiated following an increase in the minimum wage and the entire collectively agreed wage grid is pushed upwards (Bosch and Weinkopf 2013b). Such renegotiations began even before the introduction of the minimum wage. From 2010 onwards, the trade unions, anticipating the arrival of the minimum wage, had sought to raise collectively agreed rates above the $€ 8.50$ level, which they largely succeeded in doing. In 2010, 16 per cent of all pay grades in 31 industries were still below the $€ 8.50$ mark. By 2017, this applied to only 1 per cent of the pay grades in seven industries (Bispinck and Tarifarchiv 2017a). These included collective agreements that had not been 


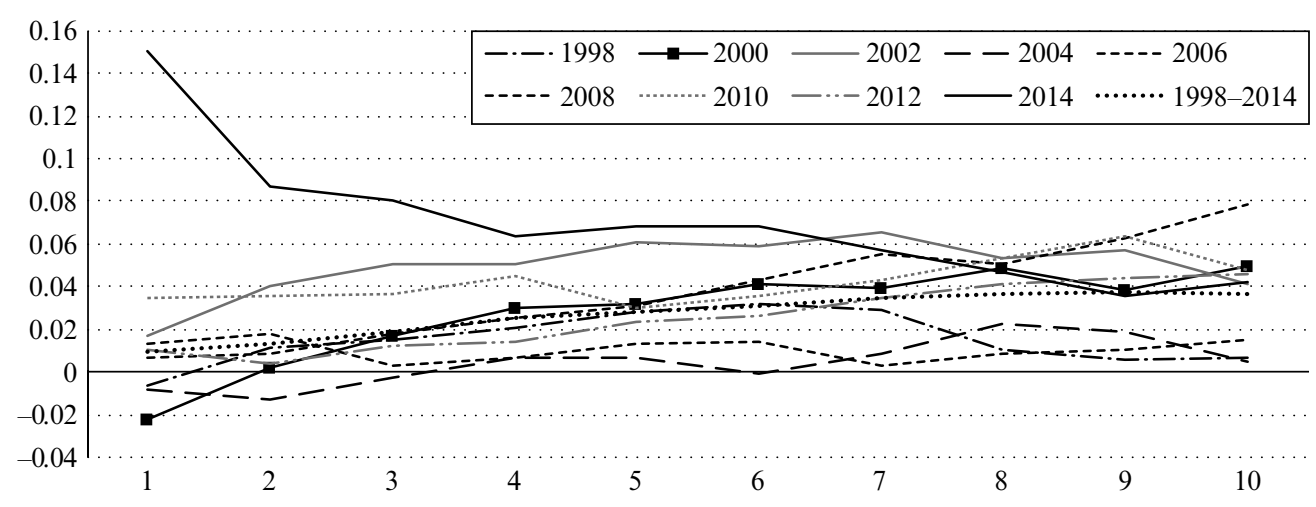

Source: Burauel et al. (2017, p. 1110).

Figure 5.12 Nominal growth in contractual hourly pay over two years by deciles, Germany, 1998-2014

renegotiated for a long time because the trade unions in those industries are too weak to force the employees into negotiations. Examples include the metal craft industry in Saxony and agriculture in Mecklenburg-Vorpommern (Figure 5.13). The ripple effects are most strongly institutionalised in those industries in which the lowest pay grade is close to the minimum wage, as in system catering. In those sectors in which the trade unions are strong, such as in public services, Deutsche Post or the metalworking and chemical industry, the lowest pay grades are significantly higher than the minimum wage, so that an increase in the minimum wage does not generate any pressure for new negotiations. Since the minimum wage is quasi-indexed, these sectors tend to pull it upwards. In the construction industry, the lowest pay grade is the same as the industry-specific minimum wage, which is negotiated by the social partners and was raised from 1 January 2018 to $€ 11.75$. The pay grade for skilled workers has also been fixed as the minimum wage II at $€ 14.95$. Industry-specific minimum wages have been negotiated in 15 industries employing a total of around 3.8 million workers. The largest of these industries are cleaning (983 000 employees), care work (870000 employees) and construction (527000 employees) (Deutscher Bundestag 2017, p. 2).

In summary, the German minimum wage has helped to improve substantially the finances of low-wage workers, and without disemployment effects. The minimum wage has also strengthened the social dialogue because it had been placed in the hands of the social partners to a much greater extent than in almost all other European countries, with the exception of Belgium. 


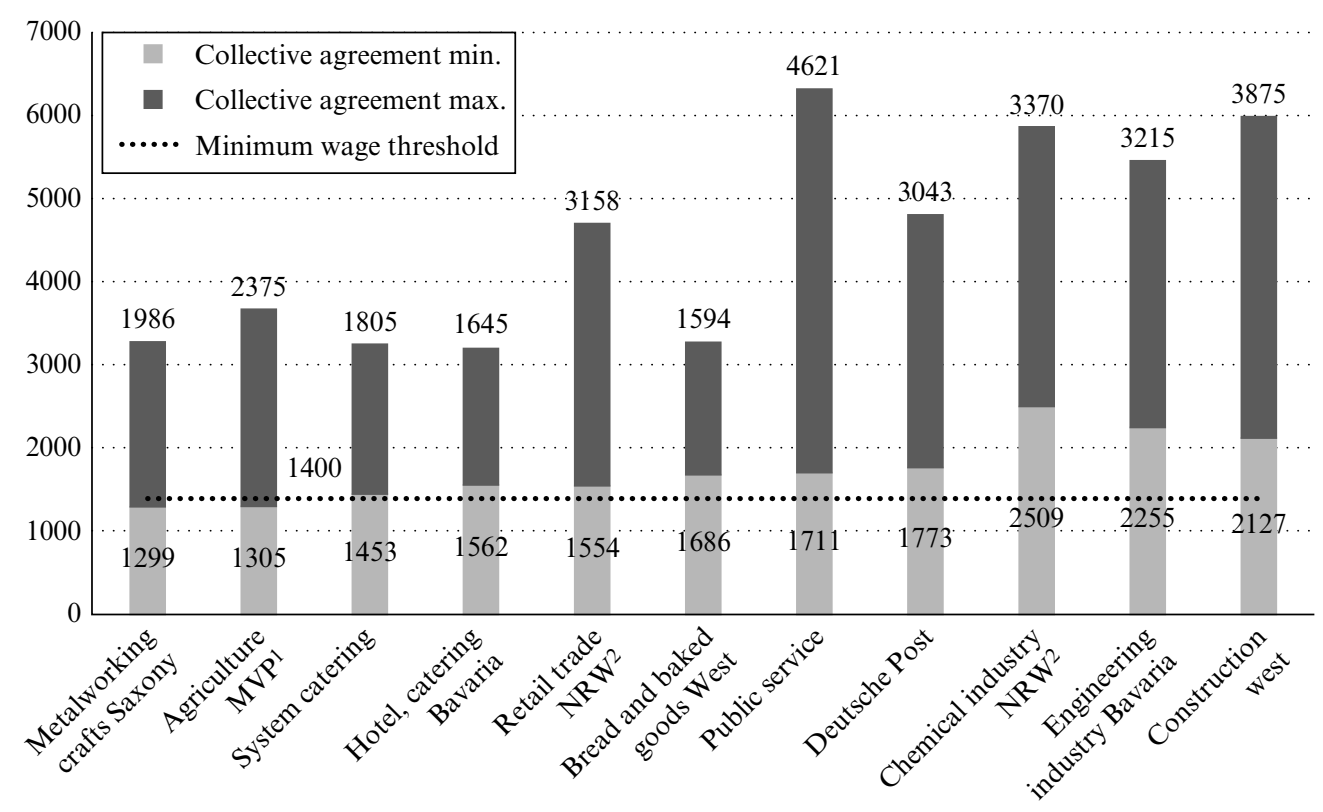

Notes:

* Monthly pay with minimum wage at $€ 8.50$ and 38 -hour week. With minimum wage at $€ 8.84$ (from 1 January 2016) monthly pay is $€ 1456$.

1 Mecklenburg-Western Pomerania.

2 North Rhine-Westphalia.

Source: Bispinck and Tarifarchiv (2017b), author's diagram.

Figure 5.13 Minimum wage and minimum and maximum rates in selected collective agreements, Germany, end of 2016

\section{CONCLUSIONS}

The starting question for this chapter was how far the social partners in Germany promote convergence within the EU. A distinction was made between beta-convergence (catch-up processes in the less developed countries) and sigma-convergence (growing inequality within individual countries). Neither form of convergence will occur of its own accord; there must be a political will to achieve it and it has to be actively managed. Industrial relations cannot make a significant contribution to these processes unless the social partners also have adequate power resources at their disposal.

It has become evident that the power resources of the trade unions in particular have declined significantly in recent decades, which has led to the emergence in Germany of a segmented labour market, as in some other EU countries. This was the intended result of government policy: the deregulation of product and labour markets undermined collective agreement coverage and led to the development of large areas of the economy outside the reach of collective agreements, in which the social partners are no longer able jointly to determine working and employment conditions. 
The weakening of the social partnership has far-reaching consequences not only for Germany but also for the EU, particularly the euro zone. Income inequality in Germany has risen sharply, which has significantly curbed sigma-convergence in Europe. For the same reason, German unit labour costs increased at a considerably slower rate than in other euro-zone countries. However, Germany's growing current account surpluses cannot be attributed solely to German wage policy. An almost equally important factor is Germany's restrictive fiscal policy, which has curbed demand for imports as a result of cuts in public investment. Germany's current account surpluses are a major factor in the destabilisation of the euro zone. They have forced other member states, the southern European deficit countries in particular, to implement wage reductions and reduce public investment, with negative effects on beta-convergence within Europe. Since German exports are not very price-sensitive, however, the current account surpluses cannot be reduced solely by higher wage increases but at the same time require an increase in public investment in Germany.

The growing income inequality is closely linked to the increase in precarious employment forms, which companies often use as a means of exiting the primary labour market segment, where employment and working conditions are good, and which is regulated by collective agreements and codetermination. Most of these precarious employment forms arise out of domestic legislation, such as the exemption of mini-jobs from income tax and social insurance contributions and, in the case of temporary agency work, the possibility of derogating from the equal pay requirement by negotiating a collective agreement to that effect. Others, such as the supply of marginal part-time jobs, depend on regulatory gaps. The trade unions are trying to get these precarious employment forms re-regulated; however, they are succeeding only where they are strong. Thus the well-organised unions in manufacturing industry negotiated wage supplements that increase as the length of an assignment in their industry increases. Insurable part-time jobs and mini-jobs are found mainly in service industries, in which the trade unions are not in a position to call strikes. In these industries, it has been possible only to negotiate isolated protection regulations for these workers. The European directives on the equal treatment of parttime and temporary employment have established minimum conditions that have become particularly important in the secondary employment segment in Germany. However, this does not apply to foreign contract workers. In their case, the Posted Workers' Directive and judgments by the Court of Justice of the European Union that gave precedence to European competition law over national collective agreements, unless they have been declared generally binding, have reduced the room for manoeuvre. In the autonomous German wage system, in which the state did not intervene in wage-setting, this European legislation eroded national collective agreements, which in effect were declared obstacles to competition. As a result, Germany became the main destination country in Europe for cost-driven postings, with devastating consequences for the working and employment conditions in the most badly affected sectors.

The growing income inequality and the undesired opening up of the German labour market to wage dumping in the shape of cheap foreign contract workers led to the introduction first of industry-specific minimum wages and then, in 2015, of a statutory minimum wage. The minimum wage has led to considerable wage increases, particularly for employees in small firms and in precarious jobs, although it has not yet been implemented everywhere owing to inadequate compliance monitoring. At the same time, the 
minimum wage has also had effects on collectively agreed wages. In industries in which the lowest collectively agreed rate is close to the minimum wage, the entire wage grid is raised when the minimum wage is increased. However, these ripple effects are considerably weaker than in France, because many low-wage sectors have low rates of collective agreement coverage.

Working time is a fundamental area of influence for the social partners, in which collectively agreed standards still have a considerable effect even in sectors not covered by collective agreements. Most employees have agreed working times of less than 40 hours per week, although in some firms not covered by collective agreements derogation clauses and new agreements have raised working times again. In industries with high levels of collective agreement coverage, the trade unions have been successful in negotiating arrangements whereby individuals can temporarily reduce their working times, with a right to return to full-time work subsequently. These agreements indicate a paradigm shift in trade union working time policy away from across-the-board reductions to more working time options over working life. Compared with the European average, the share of marginal part-time work in Germany is very high. This is due to the strong financial incentives in the tax and social security system to take a mini-job. Mini-jobs are associated with strong scarring effects. However, the reform about which the EC has issued repeated reminders has not yet happened because of the numerous special interests that have a stake in this precarious employment form. Above all, it has become evident that the increasingly unequal distribution of working time is an important factor in rising income inequality. Better regulation of minimum working times is required, not only in Germany but also in other EU member states.

The German example confirms my initial argument that the debate on convergence within the EU cannot be conducted on a country by country basis. In a common economic area, and even more so in a monetary union, a policy adopted by one country, particularly a large one, can have both positive and negative effects on convergence processes in the others. Above all, growing income inequality in Germany, combined with austerity policy, has had negative effects on beta- and sigma-convergence in other EU member states.

In the end, what matters for the improvement of the labour market situation via wage moderation in the problem countries is Germany's willingness to accept a certain deterioration of its price competitiveness. This leads to the insight that any attempt to improve a country's competitiveness via wage moderation has the character of a zero-sum game. For Germany, this strategy worked as long as the other member states remained passive or even accepted excessively high wage increases. Due to the impact of high unemployment rates in several member states, this is no longer the case. (Bofinger 2017, pp. 356-7)

However, many innovative collective agreements concluded by the German social partners, such as the recent agreements on a working-time policy that offers greater flexibility over the various phases of working life, could serve as models for other countries and promote EU convergence towards a better work-life balance. 


\section{NOTES}

1. The favourability principle in the German Collective Bargaining Act laid down a clear hierarchy of norms. The norms enshrined in an industry-level collective agreement could not be undercut by company agreements unless the collective agreements expressly permitted such undercutting.

2. The gaps between the share of the intermediate stratum in the economically active population and in the population as a whole are large, because most pensioners have no market income.

3. See http://appsso.eurostat.ec.europa.eu/nui/show.do?dataset=earn_ses_pub1t\&lang=de (accessed 28 February 2008).

4. The goal was defined in the following terms in the Council Resolution of 1974: 'Improvement of living and working conditions so as to make possible their harmonisation while the improvement is maintained' (Krebber 2009, p. 879).

5. These certificates give only an imprecise picture of the number of posted workers. Contract workers can be posted several times a year and to several different countries, so that according to estimates by the EC the number of posted contract workers is only 54 per cent of the certificates issued (EC 2017a). Moreover, not all postings are notified and certificates can be issued without the intended posting actually taking place.

6. 'Work disincentives, especially for second earners, remain in place... This contributes to a low proportion of women working full-time and one of the lowest numbers of hours worked on average by women in the Union, despite a high female employment rate ... The exemption of mini-jobs from personal income tax - and in many cases from all employee social contributions - can discourage workers from moving into jobs with earnings above the mini-job threshold of EUR 450 per month. This disincentive is in many cases even stronger for spouses subject to joint income taxation.' (EC 2016b, p. C 2999/11).

7. The Kaitz index represents the ratio of the nominal statutory minimum wage to the median wage of fulltime employees.

\section{REFERENCES}

Albu, N., A. Herzog-Stein, U. Stein and R. Zwiener (2017), 'Arbeitskosten steigen in Europa sehr verhalten. Arbeits- und Lohnstückkostenentwicklung 2016 im europäischen Vergleich', IMK Report No. 128, Institut für Makroökonomie und Konjunkturforschung, Dusseldorf.

Bach, S., M. Beznoska and V. Steiner (2016), 'Wer trägt die Steuerlast in Deutschland? Steuerbelastung nur schwach progressiv', DIW-Wochenbericht, 51-2, 1207-16.

Berg, P., G. Bosch and J. Charest (2014), 'Working-time configurations: a framework for analysing diversity across countries', Industrial \& Labor Relations Review, 67 (3), 805-37.

Bispinck, R. and WSI-Tarifarchiv (2017a), 'WSI Niedriglohn-Monitoring 2017. Mindestlöhne und tarifliche Niedriglöhne im Jahr 2017', Elemente qualitativer Tarifpolitik No. 83, Dusseldorf.

Bispinck, R. and WSI-Tarifarchiv (2017b), Statistisches Taschenbuch Tarifpolitik, Dusseldorf.

Bofinger, P. (2017), 'Hartz IV: the solution to the unemployment problems in the eurozone?', Intereconomics, 52 (6), 353-7.

Bosch, G. (2017), 'Normalarbeitsverhältnis', in H. Hirsch-Kreinsen and H. Minssen (eds), Lexikon der Arbeits- und Industriesoziologie, Berlin: Edition Sigma, pp. 246-50.

Bosch, G. (2018), 'The making of the German minimum wage', Industrial Relations Journal, 49 (1), 34-49.

Bosch, G. and T. Kalina (2016), 'The erosion of the German middle class', Intereconomics, 51 (2), 73-7.

Bosch, G. and T. Kalina (2018), 'Rising inequality of individual and household income in Germany', in B. Nolan (ed.), Inequality and Inclusive Growth in Rich Countries: Shared Challenges and Contrasting Fortunes, Oxford: Oxford University Press, pp. 153-87.

Bosch, G. and S. Lehndorff (2017), 'Autonomous bargaining in the shadow of the law: from an enabling towards a disabling state?', in D. Grimshaw, C. Fagan, G.L. Hebson and I. Tavora (eds), Making Work More Equal. A New Labour Market Segmentation Approach, Manchester: Manchester University Press, pp. 35-51. 
Bosch, G. and C. Weinkopf (2013a), 'Transnational labour markets and national wage setting systems in the EU', Industrial Relations Journal, 44 (1), 2-19.

Bosch, G. and C. Weinkopf (2013b), 'Wechselwirkungen zwischen Mindest- und Tariflöhnen', WSI-Mitteilungen, 66 (6), 393-404.

Bosch, G., T. Kalina and C. Weinkopf (2014), '25 Jahre nach dem Mauerfall - Ostlöhne holen nur schleppend auf', IAQ-Report No. 2014-05, Institut Arbeit und Qualifikation, Duisburg.

Bundesagentur für Arbeit (2017), 'Aktuelle Entwicklungen der Zeitarbeit', in Berichte: Blickpunkt Arbeitsmarkt Juli 2017, Nuremberg.

Burauel, P., M. Caliendo, A. Fedorets, M.M. Grabka, C. Schröder, J. Schupp, et al. (2017), 'Mindestlohn noch längst nicht für alle - Zur Entlohnung anspruchsberechtigter Erwerbstätiger vor und nach der Mindestlohnreform aus der Perspektive Beschäftigter', DIW Wochenbericht, 49, 1109-23.

Carlin, W. and D. Soskice (2009), 'German economic performance: disentangling the role of supply-side reforms, macroeconomic policy and coordinated economy institutions', Socio-Economic Review, 7 (1), 67-99.

Deutscher Bundestag (2017), 'Antwort der Bundesregierung auf die Kleine Anfrage der Abgeordneten Beate Müller-Gemmeke, Lisa Paus, Dr. Tobias Lindner, weiterer Abgeordneter und der Fraktion BÜNDNIS 90/DIE GRÜNEN - Drucksache 18/11304 - Finanzkontrolle Schwarzarbeit: Kontrolle von Mindestlöhnen 2016', Deutscher Bundestag, Berlin.

Dustmann, C., B. Fitzenberger, U. Schönberg and A. Spitz-Oener (2014), 'From sick man of Europe to economic superstar: Germany's resurgent economy', Journal of Economic Perspectives, 28 (1), 167-88.

Euroactiv (2013), 'Germany under EU scrutiny for current account surplus', 14 November, accessed 5 March 2018 at https://www.euractiv.com/section/euro-finance/news/germany-undereu-scrutiny-for-current-account-surplus/.

European Commission (EC) (2012), 'Current account surpluses in the EU', European Economy 9/2012, Brussels.

European Commission (EC) (2014), 'Macroeconomic imbalances Germany 2014, European economy', Occasional Papers 174, March, Brussels.

European Commission (EC) (2015a), 'Employment and social developments in Europe 2015', Brussels.

European Commission (EC) (2016a), 'Posting of workers - report on A1 portable documents issued in 2015', Brussels.

European Commission (EC) (2016b), 'Empfehlungen des Rates vom 12. Juli 2016 zum nationalen Reformprogramm Deutschlands 2016 mit einer Stellungnahme des Rates zum Stabilitätsprogramm Deutschlands 2016', Official Journal of the European Union (2016/C 299/05).

European Commission (EC) (2017a), 'Employment and social developments in Europe 2017', Brussels.

European Commission (EC) (2017b), 'European Pillar of Social Rights', accessed 28 February 2018 at https://ec.europa.eu/commission/sites/beta-political/files/social-summit-european-pillarsocial-rights-booklet_en.pdf.

Financial Times (2016), 'Why German wages need to rise - and fast', Financial Times, 16 November.

Fischer, G., S. Gundert, S. Kawalec, F. Sowa, J. Stegmaier, K. Tesching, et al. (2015), 'Situation atypisch Beschäftigter und Arbeitszeitwünsche von Teilzeitbeschäftigten - Quantitative und qualitative Erhebung sowie begleitende Forschung IAB', Forschungsprojekt im Auftrag des Bundesministeriums für Arbeit und Soziales, Nuremberg.

Fitzenberger, B. (2012), 'Expertise zur Entwicklung der Lohnungleichheit in Deutschland', Sachverständigenrat zur Begutachtung der Gesamtwirtschaftlichen Entwicklung No. 4/2012, Wiesbaden.

Gornig, M., C. Michelsen and K. van Deuverden (2015), 'Kommunale Infrastruktur fährt auf Verschleiß', DIW Wochenbericht, 43, 1023-30.

Greifenstein, R., L. Kißler and H. Lange (2011), 'Trendreport Betriebsratswahlen 2010', HansBöckler-Stiftung Working Paper No. 231, Dusseldorf.

Hanau, P. (1997), 'Sozialdumping im Binnenmarkt', in J. Baur and C. Watrin (eds), Recht und Wirtschaft der Europäischen Union, R.I.Z. Schriften, vol. 6, Berlin and New York, pp. 145-56. 
Hanau, P. (2006), 'Das Rätsel Minijob, Neue Zeitschrift für Arbeitsrecht', Zweiwochenschrift für die betriebliche Praxis, 15, 809-11.

Hassel, A. (2014), 'The paradox of liberalization - understanding dualism and the recovery of the German political economy', British Journal of Industrial Relations, 52 (1), 57-81.

Hohlfeld, P., K. Rietzler, S. Stephan, T. Theobald, S. Tober and S. Watzka (2017), 'Aufschwung breit aufgestellt, Prognose-Update: Die konjunkturelle Lage in Deutschland zur Jahreswende 2017/2018', IMK Report No. 132, Institut für Makroökonomie und Konjunkturforschung, Dusseldorf.

Horn, G.A., F. Lindner, S. Stephan and R. Zwiener (2017), 'The role of nominal wages in trade and current account surpluses', IMK Report No. 125e, Institut für Makroökonomie und Konjunkturforschung, Dusseldorf.

IG Metall (2017), Die Befragung 2017. Arbeitszeit - Sicher, gerecht und selbstbestimmt. Ergebnisse, Zahlen und Fakten zur Arbeitszeit, Frankfurt: IG Metall.

Jaehrling, K., I. Wagner and C. Weinkopf (2016), 'Reducing precarious work in Europe through social dialogue: the case of Germany. Produced for the EC project 'Reducing precarious work in Europe through social dialogue', DG Employment, Social Affairs and Equal Opportunities Project VP/2014/004 (Industrial Relations \& Social Dialogue) with the support of Thorsten Kalina and Gerhard Bosch, European Commission, Employment, Social Affairs and Inclusion DG, Brussels.

Kalina, T. and C. Weinkopf (2017), 'Niedriglohnbeschäftigung 2015 - bislang kein Rückgang im Zuge der Mindestlohneinführung', IAQ-Report No. 2017-06, Institut Arbeit und Qualifikation, Duisburg.

Komninos, N., B. Musyck and A.I. Reid (2014), 'Smart specialisation strategies in south Europe during crisis', European Journal of Innovation Management, 17 (4), 448-71.

Korpi, W. (2006), 'Power resources and employer-centered approaches in explanations of welfare states and varieties of capitalism: protagonists, consenters, and antagonists', World Politics, 58 (2), 167-206.

Krebber, S. (2009), 'Status and potential of the regulation of labor and employment law at the European level', Comparative Labor Law Policy Journal, 4, 875-903.

Lehndorff, S. (ed.) (2015), Divisive Integration. The Triumph of Failed Ideas in Europe - Revisited, Brussels: ETUI.

Lèvesque, C. and G. Murray (2010), 'Understanding union power: resources and capabilities for renewing union capacity', European Review of Labour and Research, 16 (3), 333-50.

Monti, M. (2010), 'A new strategy for the single market. At the service of Europe's economy and society', Report to the President of the European Commission José Manuel Barroso, accessed 28 February 2018 at http://ec.europa.eu/internal_market/strategy/docs/monti_report_final_10_05_ 2010_en.pdf.

Ostry, J.D. and A.G. Berg (2014), 'Measure to measure', Finance and Development, 51 (3), $35-8$

Palier, B. and K. Thelen (2010), 'Institutionalizing dualism: complementarities and change in France and Germany', Politics \& Society, 38 (1), 119-48.

Palley, T.I. (2013), 'Europe's crisis without end: the consequences of neoliberalism', Contributions to Political Economy, 32 (1), 9-50.

Sachverständigenrat zur Begutachtung der gesamtwirtschaftlichen Entwicklung (SVR) (2017), 'Für eine zukunftsorientierte Wirtschaftspolitik', Jahresgutachten 2017/18, Paderborn.

Schmid, K.D. and M. Adler (2013), 'Factor shares and income inequality, evidence from Germany 2002-2008', Journal of Applied Social Science Studies, 13 (2), 122-32.

Schulten, T. (2017), 'WSI-Mindestlohnbericht 2017 - Hohe Zuwächse in Europa', WSIMitteilungen, 70 (2), 135-41.

Sengenberger, W. (1994), 'Protection - participation - promotion: the systemic nature and effects of labour standards', in W. Sengenberger and D. Campbell (eds), Creating Economic Opportunities: The Role of Labour Standards in Industrial Restructuring, Geneva: ILO, pp. 45-60.

Springford, J. and S. Tilford (2014), 'Why Germany's trade surplus is bad for the eurozone John', CER Bulletin, (93), December 2013/January 2014, accessed 5 December 2018 at https:// www.cer.eu/sites/default/files/publications/attachments/pdf/2013/bulletin_93_js_st_article2-816 4.pdf. 
Streeck, W. (2009), Re-forming Capitalism: Institutional Change in the German Political Economy, Oxford: Oxford University Press.

Vaughan-Whitehead, D. (ed.) (2016), Europe's Disappearing Middle Class? Evidence from the World of Work, Cheltenham, UK and Northampton, MA, USA: Edward Elgar and Geneva: ILO.

Visser, J. (2016), 'Institutional Characteristics of Trade Unions, Wage Setting, State Intervention and Social Pacts (ICTWSS). An international database', version 5.1, Amsterdam Institute for Advanced Labour Studies (AIAS), Amsterdam.

Visser, J. and A. Hemerijck (1997), A Dutch Miracle: Job Growth, Welfare. Reform and Corporatism in the Netherlands, Amsterdam: Amsterdam University Press.

Waltermann, R. (2010), 'Abschied vom Normalarbeitsverhältnis? - Welche arbeits- und sozialrechtlichen Regelungen empfehlen sich im Hinblick auf die Zunahme neuer Beschäftigungsformen und die wachsende Diskontinuität von Erwerbsbiographien? Gutachten für den 68. Deutschen', Juristentag, Bonn.

Weinkopf, C. and F. Hüttenhoff (2017), 'Der Mindestlohn in der Fleischwirtschaft', WSIMitteilungen, 70 (7), 533-9.

Wolf, M. (2000), 'Von der “Konzertierten Aktion” zum "Bündnis für Arbeit”, UTOPIE kreativ, (117), July, 669-8.

Wolter, P. (2016), Neoliberale Denkfiguren in der Presse. Wie ein Wirtschaftskonzept die Meinungshoheit eroberte, Marburg: Metropolis - Verlag für Ökonomie, Gesellschaft u. Politik. 